ПРОСТОРНИ РАЗМЕШТАЈ И СТАРОСНА СТРУКТУРА СТАНОВНИШТВА КАО ФАКТОР ОГРАНИЧЕБА (РАВНОМЕРНОГ) РАЗВОЈА СРБИЈЕ

\title{
SPATIAL DISTRIBUTION AND AGE STRUCTURE OF POPULATION AS THE LIMITING FACTOR FOR (BALANCED) DEVELOPMENT OF SERBIA
}

\author{
Весна Јокић* \\ рад примљен: новембра 2013, рад прихваћен: децембра 2013.
}

\section{Апстракт}

Становништво, (људски ресурси) носиоци су економског и социјалног развоја. Демографски развој обликован природном (рађање и умирање) и механичком компонентом (досељавање) одсељавање), а представљен променама у броју и структурама становништва може да стимулише, успорава или буде ограничење економског, социјалног и укупног просторног развоја.

Демографске промене у Србији у првој деценији 21. века представљају наставак негативних тендеција започетих у последњој деценији 20. века, значајно подстакнутих политичким и друштвено-економским процесима. У последњој деценији промене су биле интензивније, демографски развој су обележиле изразита депопулација, слабљење демографских потенцијала и старење становништва. Ово је за последицу имало и повећање неравномерности у територијалном размештају становништва (драстично пражњење сеоских и неразвијених подручја).

Циљ овог истраживања је анализа демографских промена у Србији у последњем међупописном периоду, просторног размештаја и старосне структуре становништва као фактора развоја, односно ограничења равномерног развоја.

Кључне речи: становништво, старосна структура, насеља, миграције, депопулација

\section{Abstract}

The population (human resources) is the bearer of economic and social development. The demographic development is shaped by natural (birth and death) and by migration components (immigration/emigration); when is presented by changes in the number and structures of the population, it can be stimulating, slowing down or can be a limitation for economic, social and spatial development.

Demographic changes in Serbia in the first decade of the 21st century are a continuation of the negative tendencies which began in the last decade of the 20th century, substantially fuelled initiated by political and socioeconomic processes. In the last decade, the changes were more intensive and demographic development was marked by extremly depopulation, weakening of demographic potential and aging population. This has resulted in an increase disparity in the territorial distribution of the population (drastically discharge of rural and undeveloped areas).

The aim of this research is to analyze the demographic changes in Serbia in the last intercensal period, spatial distribution and age structure of the population as a factor of development / constraints of balanced development.

Keywords: population, age structure, settlements, migrations, depopulation.
Становништво, односно људски

ресурси, представља значајну одредницу економског и социјалног развоја. Демографски, економски и социјални развој су међусобно повезани и условљени. Наиме, размештај и развој становништва и његових обележја (структура) су под дирекним или индиректним утицајима економског и социјалног

развоја. Истовремено, промене у развоју становништва (кретање броја становника, размештај становништва, природни прираштај, миграције, демографске структуре) делују на економски и социјални развој, било да га стимулишу или успоравају. Демографски развој је један од главних изазова у остваривању одрживог/уравнотеженог развоја, посебно са становишта будуће организације друштва, расположивих ресурса радне снаге, социјалне и територијалне кохезије и општег економског и социјалног напретка

заједнице.

Концепт одрживог развоја подразумева постојање потребног степена демографске стабилности и уравнотежености функционалних контигената у друштвеној заједници и њеним регионалним подручјима. Овај концепт налаже да се у анализу укључе и социоекономски и структурни фактори, од којих зависи положај појединих територијалних група у коришћењу расположивих ресурса.

Локална заједница, као непосредни корисник простора, треба да буде најзаинтересованији актер у утврђивању

развојних програма и пројеката који се тичу „њеног" простора, посебно у погледу јачања хуманог капитала.

\footnotetext{
Рад је резултат истраживања спроведеног у оквиру научног пројекта ИиИ 47014 Улога и имплементација државног просторног плана и регионалних развојних докумената у обнови стратешког истраживања, мишљења и управљања у Србији, који финансира Министарство просвете, науке и технолошког развоја Републике Србије, у периоду од 2011. до краја 2014. године.

* мр Весна Јокић, истраживач сарадник, Институт за архитектуру и урбанизам Србије, Булевар краља Александра 73/II, vesna@iaus.ac.rs
} 
Крајем 20. и почетком 21. века, демографски развој, односно демографске промене, међу којима посебно старење становништва и његова просторна димензија, задобија све већу пажњу стручне и шире јавности.

Територијална димензија неравномерности размештаја становништва (првенствено депопулација у руралними, неразвијеним и девастираним подручјима), која укључује не само бројност (величину популације) већ и старосну и остале структуре, покреће питања колико је, на којим деловима територије и у ком обиму демографски развој лимитирајући фактор економског и социјалног развоја заједнице. Ово захтева да свака земља, у зависности од социоекономске развијености и перспективе демографских промена, понуди и врло конкретне одговоре.

У раду се даје преглед демографског развоја у Србији и анализирају промене/кретање броја њених становника у првој деценији 21. века, старосна структура и регионална дистрибуција, на основу које се сагледава дебаланс простора Србије у погледу расположивости потенцијала. Старосна структура становништва одражава континуитет из претходних периода, а у зависности од достигнутог степена процеса старења има последице на: демографски развој - репродукција становништва, економски развој - формирање радног контингента и социјални развој - питање задовољавања повећаних здравствених, социјалних и других потреба и захтева реформе у многим областима. 36ог свега тога, питање старења становништва мора да буде високо рангирано у спровођењу популационих, економских и социјалних политика.

\section{ДЕМОГРАФСКИ РАЗВОЈ У СРБИЈИ}

Брза трансформација Србије из претежно аграрне у средње развијену земљу, после Другог светског рата, имала је значајне последице на просторни размештај и демографски развој. Процеси индустријализације, урбанизације и деаграризације одвијали су се у свим земљама, различитим темпом, модалитетима и последицама на просторну организацију. У Србији они су се одвијали стихијски и неконтролисано, што је условило јаке унутрашње миграције на релацији село - град и у правцу неколико највећих градова (Београд, Нови Сад...) и проузроковало озбиљне поремећаје и неравнотеже, како у погледу структуре активности, тако и у погледу демографских обележја у регионалним подручјима.

Политичко опредељење за развој индустрије и урбоцентрични развој, уз економску и социјалну маргинализацију селау којимаје 50-ихгодинапрошлог века живело преко 70\% становништва, просто су „подстицали" одлазак са села. Село је маргинализовано, остајући без потребне развојне подршке од стране државних и друштвених институција. Није постојао интерес власти ни развојних актера за разумевање социјалних процеса на тим просторима, нити за подстицање и коришћење њихових специфичних ресурса (Petovar, Vujošević, 1997).

Становништво села било је маргинализовано и ускраћено у коришћењу неких од основних социјалних права, која су била доступна становницима градских насеља (доступна здравствена заштита, пензионо осигурање, квалитетно образовање и др.). Наиме, обавезно здравствено, пензионо и инвалидско осигурање за пољопривреднике уведено је тек 1979. године, и то селективно, само за оне који су се налазили у неком облику интеграције са задругом, пољопривредним комбинатом или неким другим државним предузећем. Решење је било запошљавање једног члана домаћинства (заснивање радног односа у друштвеном сектору), што је омогућавало и свим члановима ужег домаћинства здравствену и социјалну заштиту и право на породичну пензију. Последица је била трансфер пољопривредника у непољопривредна занимања (деаграризација) и трансфер пољопривредних у мешовита домаћинства (она у којима поред прихода из пољопривреде бар један члан остварује приход из радног односа). Овај вид организације домаћинства имао је и многе друге, развојно неповољне последице. Наиме, мешовит тип домаћинства је наметнуо сеоској жени огромно оптерећење због преузимања и дела традиционално мушких послова („феминизација пољопривреде"), а да при томе жене у овим домаћинствима нису за узврат добиле никакву економску и социјалну сигурност нити самосталност, односно и даље су остале у пуној зависности од мужева, односно власника газдинства. Последица је била „бег” женске омладине из села, чиме је нарушена полна структура млађих старосних група сеоског становништва (Veselinov, 1987, Petovar, Vujošević, 1996).

Процес преразмештаја становништва и депопулације, у првој фази инициран емиграцијом, а потом и под утицајем других фактора, као што је промена демографске структуре, како због старења тако и због великог одлива првенствено женске популације, имао је за последицу опадање наталитета и биолошку депопулацију у сеоским подручјима Србије. Емиграциона, претежно сеоска, подручја губила су хумани капитал, а тиме и основне развојне шансе и перспективу. Од 1953. до 1991. године број становника у градовима повећао се за преко два пута у Централној Србији, а нешто више од једног пута у Војводини, а у осталим насељима број становника је смањен, с тим што смањивање није подједнако захватило сва насеља. Само у периоду 19611971. година у градове Централне Србије доселило се око 600.000 становника (више од половине укупно досељених за три деценије). Истовремено, из осталих насеља иселило се близу милион људи, а најинтензивније исељавање из села (око пола милиона становника) било је у овом периоду (1961-1971). У Војводини се од 60-их година прошлог века из сеоских насеља одселило око 300.000 становника, док су градска насеља имала позитиван миграциони салдо до 1981. године. Дуго деловање миграција исцрпело је демографске потенцијале највећег дела сеоских насеља Централне Србије и Војводине, допринело је убрзаном старењу и одразило се на природни прираштај (у периоду 1981-1990. године евидентиран је негативан природни прираштај од -36.434) (Radovanović, 1995).

Демографски проблеми у Србији, а посебно у појединим њеним деловима, све су сложенији и имају бројне негативне 
последице на развој. У последњих педесет година, од демографски прилично равномерно насељеног простора, значајан део територије Србије постао је практично испражњен. Оваква ситуација демографски је „одговор” на вишедеценијско одсуство државне подршке економском и социјалном развоју руралних подручја (комунално и инфраструктурно опремање сеоских насеља, изградња локалне саобраћајне мреже и организовање локалног међунасељског јавног превоза, директне инвестиције у индустријске програме и др.).

Последњу деценију 20. века обележило је симултано одвијања два типа транзиције: економске, која је у то време отпочела, и демографске, која је трајала деценијама пре тога (Manić, Azdejković, 2012: 117). Економски колапс привреде, вишеструко смањење друштвеног производа и дохотка по становнику, велика незапосленост, опадање стамбене изградње, урушавање система социјалне заштите и одговарајућих институција, главни су узроци негативних демографских кретања у Србији 90-их година 20. века (Jokić, Petovar, Vujošević, 1996).

Тако је појава смањења укупног становништва Србије први пут регистрована у Попису 2002. године ${ }^{2}$ (Табела 1). У Србији је 2002. године живело 7.498.001 становника, што је за 78.836 мање у односу на претходни Попис 1991. године (просечна годишња стопа -1.0\%о). Овај период су обележиле и масовне миграције које су допринеле ублажавању степена/интензитета депопулације - природни прираштај је био негативан (-162.411), а позитиван миграциони салдо ${ }^{3}$ од 85.573 ублажио је опадање броја становника изазваног природним кретањем. На подручју Војводине и Београда број становника се повећао (за 61.797, односно 23.973) и то првенствено због миграционе компоненте, док је природни прираштај био негативан. У Централној (рбији (Србија-Југ по новој номенклатури) забележено је смањење броја становника за 164.606 и при том су миграције имале доминантнији утицај $(-116.126)$ у односу на природни прираштај (-59.296).

\section{КРЕТАЊЕ БРОЈА СТАНОВНИКА У СРБИЈИ У ПЕРИОДУ 2002-2011. ГОДИНА}

Преглед кретања броја становника, као и утицаја природне и миграционе компоненте на демографске промене приказан је у Табели 1, а преглед по општинама за последњи међупописни период (2002-2011) на сликама 1-3. Подаци у табели приказани су у складу са Номенклатуром статистичких територијалних јединица (HCTJ или NUTS/Nomenclature des unités territoriales statistiques) ${ }^{4}$.
Резултати Пописа становништва 2011. године, као и подаци виталне статистике, указују да су у Србији током прве деценије 21. века не само настављени већ и убрзани негативни демографски процеси евидентирани током последње деценије 20.века. У односу на 2002. годину број становника се смањио за 311.787 лица (просечна годишња стопа -4.2\%0), тако да је 2011. године у Србији било 7.186.862 становника. Целине Србија-Север и Србија-Југ имале су приближно исти број становника (по око 3,6 милиона), а у односу на 2002. годину у обе целине је забележено смањење укупног становништва. У целини Србија-Север број становника се смањио за 16.867, а у целини Србија-Југ много више, односно за 294.272. Треба имати у виду да су становници албанске националности из Прешева и Бујановца одбили да учествују (бојоктовали) у Попису 2011. године. Тако да се може рачунати са још око 60.000 становника у овом региону. у табелама за Пчињску област дати су подаци пописаног становништва (без процене о броју становника у Бујановцу и Прешеву). Разлике у кретању становништва у ове две целине су још израженије уколико се посматра двадесетогодишњи период (1991-2011). Пре две деценије (рбија-Југ је имала преко пола милиона становника више (532.145) него СрбијаСевер, али до 2011. године становништво на Северу се повећало за 68.903, док се на Југу смањило за 458.878.

Посматрано према основним компонентама демографских промена, у последњем међупописном периоду, интензивније опадање природне компоненте обнављања становништва (просечна годишња стопа природног прираштаја -4,2\%о) главни је разлог опадања становништва (рбије, док је миграциони салдо, мада незнатан (648 лица), био позитиван. Север Србије имао је позитиван миграциони салдо (116.774 лица), што је ублажило опадање броја становника због негативног природног прираштаја (-133.644), док Југ Србије бележи опадање по обе компоненте, али је негативан природни прираштај био доминантнији у односу на миграције/емиграције (-178.146:-116.126).

\section{Регионалне разлике}

Посматрано на нивоу статистичких региона - HCTЈ 2 број становника 2011. године се кретао од око 1,6 милиона (Јужна и Источна (рбија и Београд) до око 2,0 милиона (Војводина и Шумадија и Западна (рбија). У периоду 2002-2011. година само је Београдски регион забележио пораст (за 83.316), а остали региони смањење и то: најитензивније у Региону Јужне и Источне Србије (за 189.088), мање интензивно и слично у Региону Шумадије и Западне (рбије (за 105.184) и

\footnotetext{
У Попису 2002. године примењена је нова методологија. Према овој методологији, становништво које борави у иностранству дуже од годину дана не рачуна се у стално становништво. У иностранству је 2002. године радило/боравило 412.443 грађана Републике, дуже од годину дана 395.124 лица и до годину дана 17.319 (ова лица су рачуната у стално становништво). Треба имати у виду да је број лица у иностранству већи с обзиром на могући проблем приликом пописивања ових лица - непотпуни обухват (сви чланови домаћинства су у иностранству, када се ради о лицима која већ дуго бораве у иностранству и сл.). Ради поређења демографских промена и за Попис 1991. године коришћени су подаци према новој методологији.

3 Претпоставља се да је 2002. године пописано између 400 и 480 хиљада лица која су дошла из других бивших југословенских република. Такође, око 122 хиљаде лица (102 из Централне (рбије и око 20 из Војводине) су новоотишли радници на привремени рад у иностранство или код њих пристигли чланови домаћинства (Penev, Stevanović, 2002).

4 Уредба о номенклатури статистичких територијалних јединица усвојена је 2009. године (SI. glasnik RS, br. 109/09 і 46/10). 0вом номенклатуром дефинисане су статистичке функционалне територијалне целине, тј. три хијерархијска нивоа: НСТ 1 (две функционалне целине: Србија - Север и Србија - Југ), HCTJ 2 (региони) и НСТJ 3 (области). На нивоу НСТЈ 2 су дефинисани региони и то: у оквиру Србије - Север су Београдски регион и Регион Војводине, а у саставу Србија - Југ региони Шумадија и Западна Србија, Јужна и Источна Србија и Косово и Метохија. Статистички региони се састоје од целина нивоа НCTJ 3 које су назване „области" и које се у потпуности (границе и називи) поклапају са постојећим управним окрузима.
} 


\begin{tabular}{|c|c|c|c|c|c|c|c|c|c|c|c|c|c|c|c|}
\hline \multirow{3}{*}{ Подручје } & \multirow{2}{*}{\multicolumn{3}{|c|}{$\begin{array}{c}\text { Број становника по } \\
\text { пописима }\end{array}$}} & \multicolumn{6}{|c|}{ Промене по међупописним периодима } & \multicolumn{6}{|c|}{$\begin{array}{c}\text { Просечне годишње стопе по } \\
\text { међупописним периодима }\end{array}$} \\
\hline & & & & \multicolumn{2}{|c|}{$\begin{array}{l}\text { укупан број } \\
\text { становника }\end{array}$} & \multicolumn{2}{|c|}{$\begin{array}{l}\text { природни } \\
\text { прираштај }\end{array}$} & \multicolumn{2}{|c|}{$\begin{array}{c}\text { миграциони } \\
\text { салдо }\end{array}$} & \multicolumn{2}{|c|}{ укупно } & \multicolumn{2}{|c|}{$\begin{array}{l}\text { природни } \\
\text { прираштај }\end{array}$} & \multicolumn{2}{|c|}{$\begin{array}{l}\text { миграциони } \\
\text { салдо }\end{array}$} \\
\hline & 1991 & 2002 & 2011 & $\begin{array}{l}1991- \\
2002\end{array}$ & \begin{tabular}{|l|}
$2002-$ \\
2011 \\
\end{tabular} & $\begin{array}{l}1991- \\
2002 \\
\end{array}$ & \begin{tabular}{|l|}
$2002-$ \\
2011 \\
\end{tabular} & $\begin{array}{l}1991- \\
2002 \\
\end{array}$ & \begin{tabular}{|l|}
$2002-$ \\
2011 \\
\end{tabular} & \begin{tabular}{|l|}
$1991-$ \\
2002 \\
\end{tabular} & \begin{tabular}{|l|}
$2002-$ \\
2011 \\
\end{tabular} & \begin{tabular}{|l|}
$1991-$ \\
2002 \\
\end{tabular} & \begin{tabular}{|l|}
$2002-$ \\
2011 \\
\end{tabular} & $\begin{array}{l}1991- \\
2002 \\
\end{array}$ & $\begin{array}{l}2002- \\
2011 \\
\end{array}$ \\
\hline РЕПУБЛИКА СРБИЈЕ & 7576837 & 7498001 & 7186862 & -78836 & -311139 & -162411 & -311787 & 83575 & 648 & $-1,0$ & $-4,2$ & $-2,0$ & $-4,2$ & 1,0 & 0,01 \\
\hline СРБИЈА - СЕВЕР & 3522346 & 3608116 & 3591249 & 85770 & -16867 & -103115 & -133641 & 188885 & 116774 & 2,2 & $-0,5$ & $-2,6$ & $-3,7$ & 4,8 & 3,2 \\
\hline БЕОГРАДСКИ РЕГИОН & 1552151 & 1576124 & 1659440 & 23973 & 83316 & -21944 & -33358 & 45917 & 116674 & 1,4 & 5,2 & $-1,3$ & $-2,1$ & 2,7 & 7,2 \\
\hline РЕГИОН ВОЈВОДИНА & 1970195 & 2031992 & 1931809 & 61797 & -100183 & -81171 & -100283 & 142968 & 100 & 2,8 & $-5,1$ & $-3,7$ & $-5,1$ & 6,5 & 0,01 \\
\hline Западнобачка област & 210679 & 214011 & 188087 & 3332 & -25924 & -11519 & -15463 & 14851 & -10461 & 1,4 & $-12,9$ & $-4,9$ & $-7,7$ & 6,4 & $-5,2$ \\
\hline Јужнобанатска област & 315633 & 313937 & 293730 & -1696 & -20207 & -13645 & -16339 & 11949 & -3868 & $-0,5$ & $-6,7$ & $-3,9$ & $-5,4$ & 3,5 & $-1,3$ \\
\hline Јужнобачка област & 543878 & 593666 & 615371 & 49788 & 21705 & -8934 & -12388 & 58722 & 34093 & 8,0 & 3,6 & $-1,4$ & $-2,0$ & 9,4 & 5,6 \\
\hline Севернобанатска област & 177542 & 165881 & 147770 & -11661 & -18111 & -10998 & -12475 & -663 & -5636 & $-6,2$ & $-11,5$ & $-5,8$ & $-8,0$ & $-0,4$ & $-3,6$ \\
\hline Северно-бачки област & 202493 & 200140 & 186906 & -2353 & -13234 & -12827 & -12971 & 10474 & -263 & $-1,1$ & $-6,8$ & $-5,8$ & $-6,7$ & 4,7 & $-0,1$ \\
\hline Средњебанатски област & 216754 & 208456 & 187667 & -8298 & -20789 & -14320 & -14751 & 6022 & -6038 & $-3,5$ & $-10,5$ & $-6,1$ & $-7,4$ & 2,6 & $-3,0$ \\
\hline Сремска област & 303216 & 335901 & 312278 & 32685 & -23623 & -8928 & -15896 & 41613 & -7727 & 9,3 & $-7,3$ & $-2,5$ & $-4,9$ & 11,8 & $-2,4$ \\
\hline СРБИЈА - ЈУГ & 4054491 & 3889885 & 3595613 & -164606 & -294272 & -59296 & -178146 & -105310 & -116126 & $-3,8$ & $-7,9$ & $-1,4$ & $-4,8$ & $-2,4$ & $-3,1$ \\
\hline $\begin{array}{l}\text { РЕГИОН ШУМАДИЈЕ И } \\
\text { ЗАПАДНЕ СРБИЈЕ }\end{array}$ & 2196689 & 2136881 & 2031697 & -59808 & -105184 & -24104 & -83100 & -35704 & -22084 & $-2,5$ & $-5,0$ & $-1,0$ & $-4,0$ & $-1,5$ & $-1,1$ \\
\hline Златиборска област & 332470 & 313396 & 286549 & -19074 & -26847 & 2385 & -8062 & -21459 & -18785 & $-5,4$ & $-8,9$ & 0,7 & $-2,7$ & $-6,0$ & $-6,3$ \\
\hline Колубарска област & 196556 & 192204 & 174513 & -4352 & -17691 & -7419 & -12124 & 3067 & -5567 & $-2,0$ & $-9,6$ & $-3,5$ & $-6,6$ & 1,4 & $-3,0$ \\
\hline Мачванска област & 329226 & 329625 & 298931 & 399 & -30694 & -5192 & -13851 & 5591 & -16843 & 0,1 & $-9,8$ & $-1,4$ & $-4,4$ & 1,5 & $-5,4$ \\
\hline Моравичка област & 228093 & 224772 & 212603 & -3321 & -12169 & -5810 & -10618 & 2489 & -1551 & $-1,3$ & $-5,6$ & $-2,3$ & $-4,9$ & 1,0 & $-0,7$ \\
\hline Поморавска област & 240715 & 227435 & 214536 & -13280 & -12899 & -7786 & -16662 & -5494 & 3763 & $-5,2$ & $-5,8$ & $-3,0$ & $-7,5$ & $-2,1$ & 1,7 \\
\hline Расинска област & 272834 & 259441 & 241999 & -13393 & -17442 & -7785 & -15740 & -5608 & -1702 & $-4,6$ & $-7,0$ & $-2,7$ & $-6,3$ & $-1,9$ & $-0,7$ \\
\hline Рашка област & 293311 & 291230 & 309258 & -2081 & 18028 & 13668 & 6704 & -15749 & 11324 & $-0,6$ & 6,0 & 4,3 & 2,2 & $-4,9$ & 3,8 \\
\hline Шумадијска област & 303484 & 298778 & 293308 & -4706 & -5470 & -6165 & -12747 & 1459 & 7277 & $-1,4$ & $-1,8$ & $-1,9$ & $-4,3$ & 0,4 & 2,5 \\
\hline $\begin{array}{l}\text { РЕГИОН ЈУЖНЕИ ИСТОЧНЕ } \\
\text { СРБИЈЕ }\end{array}$ & 1857802 & 1753004 & 1563916 & -104798 & -189088 & -35192 & -95046 & -69606 & -94042 & $-5,3$ & $-11,4$ & $-1,8$ & $-5,7$ & $-3,5$ & $-5,7$ \\
\hline Борска област & 163229 & 146551 & 124992 & -16678 & -21559 & -4137 & -11136 & -12541 & -10423 & $-9,8$ & $-15,9$ & $-2,4$ & $-8,2$ & $-7,4$ & $-7,7$ \\
\hline Браничевска област & 220225 & 200503 & 183625 & -19722 & -16878 & -5237 & -16109 & -14485 & -769 & $-8,5$ & $-8,8$ & $-2,3$ & $-8,4$ & $-6,3$ & $-0,4$ \\
\hline Зајечарска област & 154176 & 137561 & 119967 & -16615 & -17594 & -12055 & -13877 & -4560 & -3717 & $-10,4$ & $-13,7$ & $-7,5$ & $-10,8$ & $-2,8$ & $-2,9$ \\
\hline Јабланичкиа област & 251301 & 240923 & 216304 & -10378 & -24619 & -3178 & -12938 & -7200 & -11681 & $-3,8$ & $-10,8$ & $-1,2$ & $-5,7$ & $-2,7$ & $-5,1$ \\
\hline Нишавска област & 389838 & 381757 & 376319 & -8081 & -5438 & -12047 & -19241 & 3966 & 13803 & $-1,9$ & $-1,4$ & $-2,8$ & $-5,1$ & 0,9 & 3,6 \\
\hline Пиротска област & 115970 & 105654 & 92479 & -10316 & -13175 & -8555 & -9961 & -1761 & -3214 & $-8,5$ & $-13,3$ & $-7,0$ & $-10,1$ & $-1,4$ & $-3,2$ \\
\hline Подунавска област & 216056 & 210290 & 199395 & -5766 & -10895 & -2322 & -8940 & -3444 & -1955 & $-2,5$ & $-5,3$ & $-1,0$ & $-4,4$ & $-1,5$ & $-1,0$ \\
\hline Пчињска област 1) & 237399 & 227690 & 159081 & -9709 & -68609 & 17372 & 3344 & -27081 & -71953 & $-3,8$ & $-35,5$ & 6,8 & 1,7 & $-10,6$ & $-37,2$ \\
\hline Топличка област & 109608 & 102075 & 91754 & -7533 & -10321 & -5033 & -6188 & -2500 & -4133 & $-6,5$ & $-10,6$ & $-4,3$ & $-6,4$ & $-2,1$ & $-4,3$ \\
\hline
\end{tabular}

Извор: Природно кретање становништва у Републици Србији 1961-2010, подаци по општинама, РЗС, Београд, 2012. 1) Обухвата само пописано становништво. Уопштинама Прешево и Бујановац албанско становништво није учествовало у Попису 2011. године.

Региону Војводине (за 101.183). Сви региони су забележили негативан природни прираштај, а само је Београдски регион имао позитиван миграциони салдо и то дупло већи (116.674 лица) у односу на период 1991-2002. година (45.917 лица). Позитиван миграциони салдо су имале и области у којима се налазе велики градови/регионални центри: Нови Сад (Јужнобачка област), Ниш (Нишавска област) и Крагујевац (Шумадијска област), што је свакако резултат унутрашњих миграција усмерених ка овим центрима, али делом и резултат уписа у стално становништво интерно расељених лица са Косова и Метохије (у Попису 2002. године ова лица нису била уписана као стално становништво).

Посматрано на нивоу области - НСТЈ 3, у периоду 2002-2001. година, смањење броја становника је евидентирано у 22 од
Таб.1.

Промена укупног броја становника, природног прираштаја и миграционог салда у периодима 1991-2002. и 2002-2011. година Tab. 1.

Change of the total population, natural increase and migration balance in the period of 1991-2002. and 2002-2011.

25 области, док је повећање становништва забележено у Београдској, Јужнобачкој и Рашкој области. У овим областима су два највећа, и за мигранте најпривлачнија, града у земљи - Београд и Нови Сад, а у Рашкој области пораст бележе све општине осим Рашке - највише општина Нови Пазар (за око $17 \%$, и једина је општина која има позитиван и природни прираштај и миграциони салдо), знатно мање (око 4\%) општине Тутин, Краљево и Врњачка Бања (претпоставка је да је у Краљеву и Врњачкој Бањи пораст забележен пописивањем лица расељених са Косова, која су се у Попису 2002. године водила као интерно расељена лица и нису била укључена у укупно/стално становништво општине). Убедљиво најинтензивније смањење бележи Борска област (за око 15\%), затим Зајечарска и Пиротска (за око 13\%), све 
на подручју региона Јужне и Источне Србије. У областима на подручју региона Шумадије и Западне Србије опадање броја становника креће се од око 2\% у Шумадијској области, око $6 \%$ у Поморавској и Моравичкој до око 10\% у Колубарској и Мачванској. На подручју Војводине највеће смањење је у Западнобачкој области (око 12\%), а најмање у (ремској и Јужнобанатској (за око7\%).

Од 168 општина, односно градова, повећање становника је остварено у свега 16 (11 на подручју Београдског региона), док су градска општина Лазаревац и град Пожаревац имали скоро исти број становника као 2002. године. Апсолутно највеће процентно смањење броја становника имају Црна Трава (за 35\%) и Медвеђа (за око 30\%), затим Бабушница, Гаџин Хан и Мајданпек (20-22\%), а у 76 општина смањење износи 10\%-20\%.
Такође, досадашња транзиција у Србији највише угрожава младо становништво у унутрашњости Србије, посебно у градовима бивших социјалистичких „гиганата". Очигледан пример су Бор и Мајданпек. У периоду 2002-2011. година број становника општине Бор смањио се за око 7.200, од тога градска популација за око 5.200, а број становника општине Мајданпек за око 5.000, односно градског становништва за око 3.000. Ово је директна последица погоршања егзистенијалних услова (економски „крах" јединог развојног „гиганта" - РТБ), чиме се интензивирало исељавање, углавном млађег образованог становништва, а значајно смањило досељавање (Prostorni plan opštine Bor, Prostorni plan područja posebne namene Borskomajdanpečkog rudarskog basena - Koncept prostornog plana, IAUS, 2013).
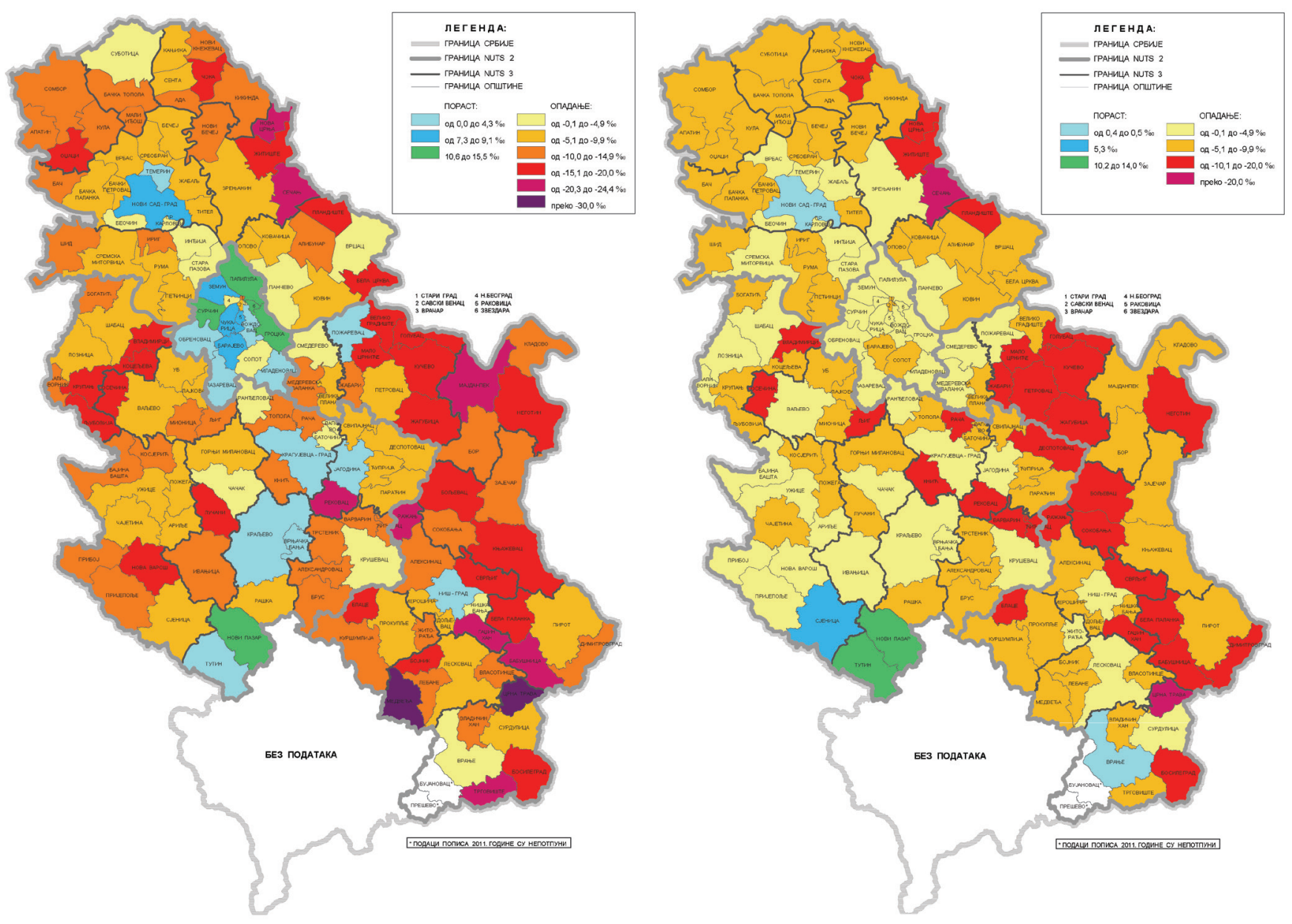

Сл.1.

Укупна просечна годишња стопа промена броја становника по општинама у периоду 2002-2011

Fig. 1

The total average annual population change rate by municipalities in the period 2002-2011
Сл. 2.

Просечне годишње стопе природног прираштаја по општинама у периоду 2002-2011

Fig. 2

The average annual natural population growth rate by municipalities in the period 2002-2011 


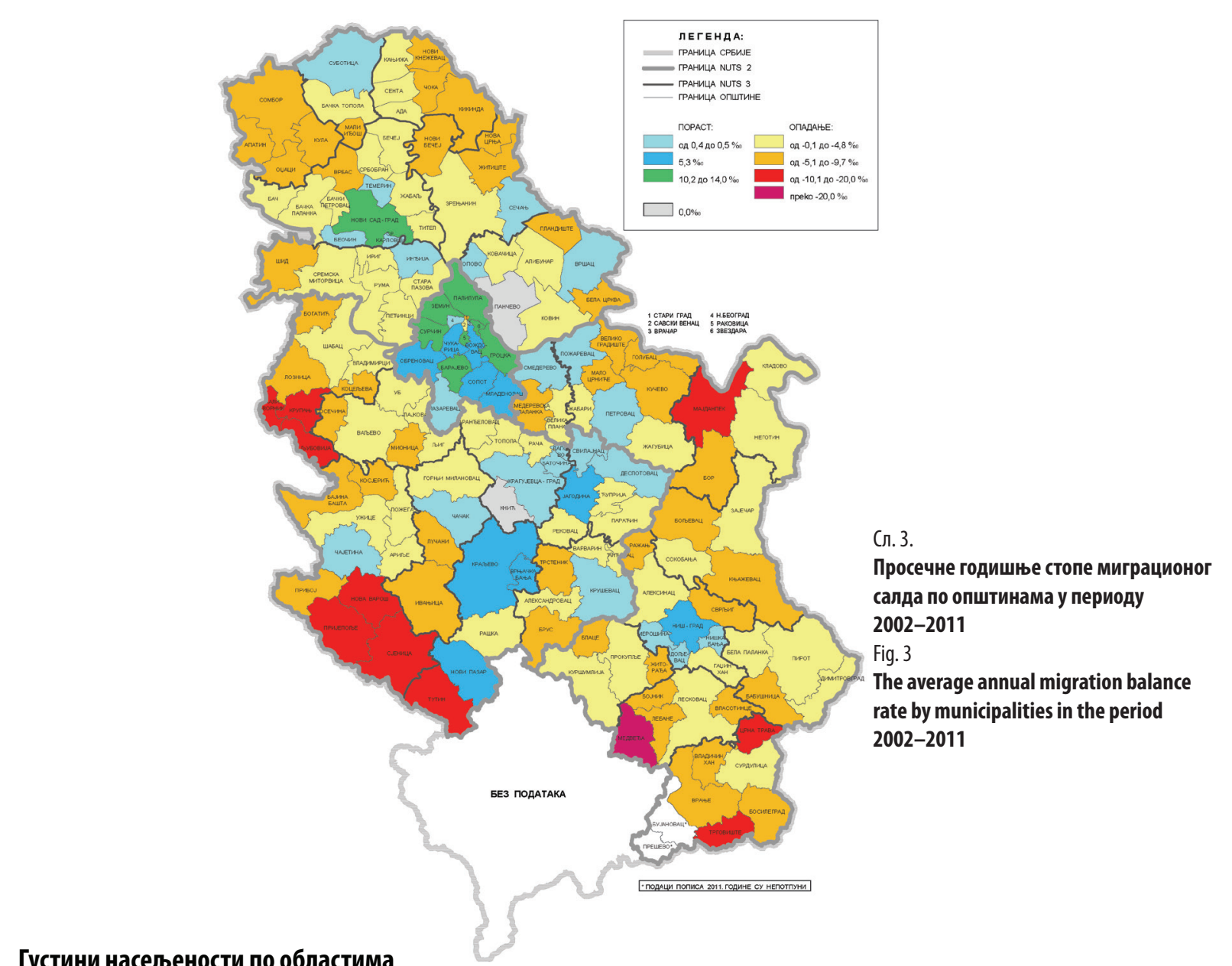

\section{Густини насељености по областима}

Испољене промене у првој деценији 21. века, инициране током последње деценије 20. века, имају значајне последице на демографски развој у Србији - депопулација скоро читавог простора државе, одмакла просторна поларизација и диспропорција (миграције усмерене углавном ка Београду и Новом Саду) и изразита „атомизација” сеоских насеља (најинтензивнија у Региону Јужне и Источне (рбије). у Београдској области, која чини око 4\% територије Србије, живи (2011) скоро четвртина (23\%) становништва Србије, а у јужнобачкој области око 9\%, тако да у ове две области $(9,3 \%$ територије (рбије) живи око трећина (32\%) становништва (рбије (Графикон 1). С друге стране, у односу на 2002. годину повећао се број слабо насељених општина (д0 $50 \mathrm{st} / \mathrm{km}^{2}$ ) са 51 на 62 (у укупној површини Србије учествују са 44\%, а у њима живи $15,2 \%$ становништва).
На велику демографску поларизацију Србије и регионалне и унутаррегионалне разлике указују и основни показатељи насељености (Табела 2) ${ }^{5}$. На Северу Србије натпросечна је насељеност (145 st $\left./ \mathrm{km}^{2}\right)$, два пута већа од насељености на Југу (рбије $\left(68 \mathrm{st} / \mathrm{km}^{2}\right)$. На константно повећање разлика у насељености ових целина указују вредности из 1991. године када је тај однос био $142: 77 \mathrm{st} / \mathrm{km}^{2}$. Београдски регион је најнасељенији $\left(518 \mathrm{st} / \mathrm{km}^{2}\right)$, а поређењем са осталим регионима иобластимавидисевеома изражена поларизација и регионална диспропорција у размештају становништва на простору Србије. Овај регион је три пута насељенији од друге по густини насељеноси Поморавске области (163 st/ $\mathrm{km}^{2}$ ), осам пута у односу на најмање насељен Регион Јужне и Источне Србије, а знатно више у односу на поједине уже територијалне целине у овом региону. У осталим регионима, веће густине насељености имају области у којима се налазе

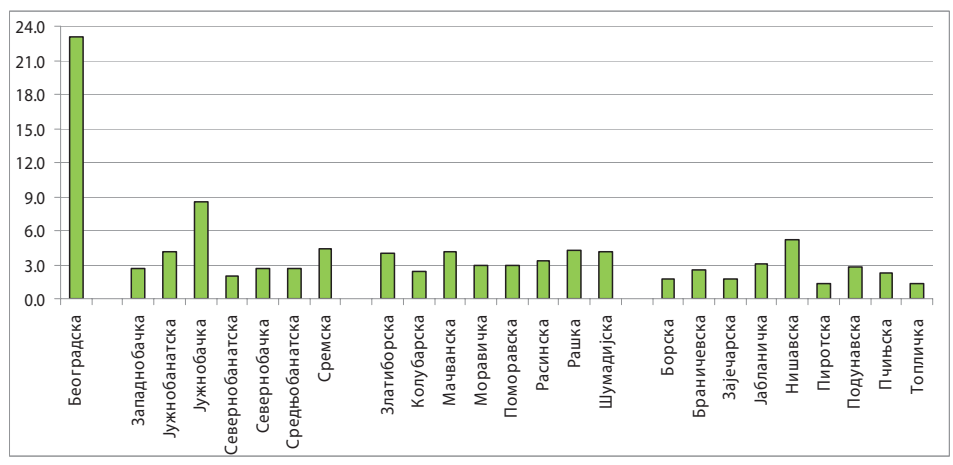

Графикон 1.

Учешће становништва области у укупном становништву Србије (у \%) - Попис 2011. Graph 1.

Share population of district in total population of Serbia(in\%) - Census 2011.

Вредности наведених показатеља зависе од просторне јединице мерења, односно прецизнији су што је просторна једница мања. Сасвим је извесно да на датим нивоима посматрања долази до „упросечавња" (не показује се право стање), али су индикативни за сагледавање односа насељености у овим просторним целинама. 


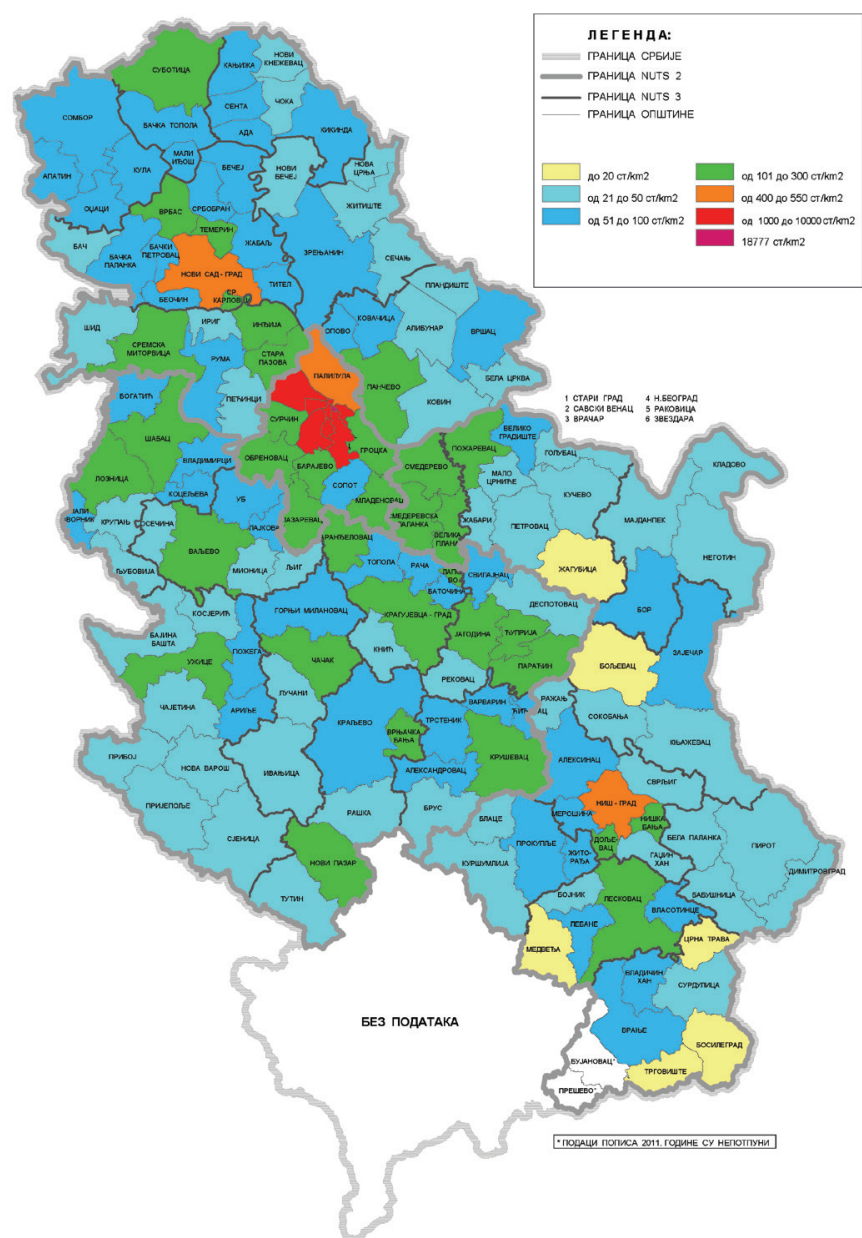

Сл. 4.

Густина насељености по општинама (st/km²) 2011.

Fig. 4.

The population density by municipality $($ per km²) 2011.

велики градови/регионални центри - Јужнобачка област (153 st $\left./ \mathrm{km}^{2}\right)$ са градом Новим Садом (489 st $\left./ \mathrm{km}^{2}\right)$, Нишавска (138 st $\left./ \mathrm{km}^{2}\right)$ са градом Нишом $\left(510 \mathrm{st} / \mathrm{km}^{2}\right)$ и Шумадијска област (124 st $\left./ \mathrm{km}^{2}\right)$ са градом Крагујевцем $\left(220 \mathrm{st} / \mathrm{km}^{2}\right)$. у односу на 1991. годину Београдска и Јужнобачка област забележиле су повећање насељености (са 484 на $518 \mathrm{st} / \mathrm{km}^{2}$ и са 135 на 153 st $/ \mathrm{km}^{2}$ ), а Нишавска и Шумадијска опадање (са 143 на 137 st $/ \mathrm{km}^{2}$, односно са 128 на 124 st $/ \mathrm{km}^{2}$ ).

Регион Шумадије и Западне Србије је насељенији од Региона Јужне и Источне (рбије $\left(77: 60 \mathrm{st} / \mathrm{km}^{2}\right)$ и са знатно мањим унутаррегионалним разликама. Најмања густина насељености је у Златиборској области (47 st $\left./ \mathrm{km}^{2}\right)$, док се у осталим областима креће од 70 до 91st/km².

Регион Јужне и Источне Србије најмање је насељен у односу на површину коју заузима. У овом региону, 2011. године најмању густину насељености имале су Зајечарска и Пиротска област (по $\left.33 \mathrm{st} / \mathrm{km}^{2}\right)^{6}$, затим Борска (36 st $\left./ \mathrm{km}^{2}\right)$, Топличка $\left(41 \mathrm{st} / \mathrm{km}^{2}\right)$ и Браничевска област $\left(48 \mathrm{st} / \mathrm{km}^{2}\right)^{7}$.

Треба имати у виду да значајан део ових области чини планинско подручје (изнад 600 м. н. В.), које је практично ненастањено.

у Пчињској области просечна густина насељености од $45 \mathrm{st} / \mathrm{km} 2$ није реална, због неучествовања албанског становништва Прешева и Бујановца у Попису 2011. године.

7 у Пчињској области просечна густина насељености од $45 \mathrm{st} / \mathrm{km} 2$ није реална, због неучествовања албанског становништва Прешева и Бујановца у Попису 2011. године.

\section{Број насеља и становника у насељима до 1000 становника}

Неколико региона у Србији има натпросечно учешће насеља са малим бројем становника. У Србији је 2011. године, од укупно 4.709 насеља, 966 (свако пето) имало мање од 100 становника. Највећа концентрација ових насеља је у региону Јужне и Источне Србије - 629 (32\% од укупног броја насеља Региона) и то углавном у Јабланичкој $(115$, тј. $30 \%$ насеља ове области), Пиротској (128, тј. 60\% насеља) и Топличкој области (143, тj. 54\% насеља). у Региону Шумадије и Западне (рбије у овој категорији је 330 насеља (16\% насеља Региона), а у Војводини 12 насеља.

Такође, у 211 насеља живело је до 20 становника (150 у Региону Јужне и Источне Србије и 61 у Региону Шумадија и Западна (рбија), а 313 насеља имало је између 20 и 50 становника (215 у Региону Јужне и Источне Србије, 94 у Региону Шумадија и Западна (рбија и четири у Војводини). Ако се додају насеља у којима има између 100 и 300 становника (1.176), следи да у скоро половини насеља $(45,6 \%)$ на подручју Србије живи до 300 становника. Највеће учешће ове категорије насеља имају области у региону Јужне и Источне Србије: Пиротска (85\% од укупног броја насеља у којима живи 16\% становништва), Топличка (83\% и 22\% становништва), Зајечарска (68\% насеља са 13\% становника) и Јабланичка (59\% и 10\% становника области), док је у Подунавској области само два насеља у овој категорији. у Региону Шумадије и Западне Србије највеће учешће је у Рашкој (66\% насеља и 9\% становника) и Златиборској 
Весна Јокић, АУ38/2013/страна 17-32/Просторни размештај и старосна структура становништва као фактор ограничења развоја Србије

\begin{tabular}{|c|c|c|c|c|c|c|}
\hline Подручје & $\begin{array}{c}\text { Број } \\
\text { насеља }\end{array}$ & $\begin{array}{c}\text { Број } \\
\text { становника } \\
\end{array}$ & $\begin{array}{c}\text { Просечно становника } \\
\text { по насељу }\end{array}$ & $\begin{array}{c}\text { Површина } \\
\left(\mathrm{km}^{2}\right)\end{array}$ & $\begin{array}{c}\text { Број насеља } \\
\text { на } 100 \text { km² }^{2} \\
\end{array}$ & $\begin{array}{c}\text { Број становника } \\
\text { на km² }^{2}\end{array}$ \\
\hline РЕПУБЛИКА СРБИЈЕ & 4709 & 7.186 .862 & 1.526 & 77.468 & 6,1 & 92,8 \\
\hline СРБИЈА - CЕВЕР & 624 & 3.591 .249 & 5.755 & 24.792 & 2,5 & 144,9 \\
\hline БЕОГРАДСКИ РЕГИОН & 157 & 1.659 .440 & 10.570 & 3.204 & 4,9 & 517,9 \\
\hline РЕГИОН ВОЈВОДИНА & 467 & 1.931 .809 & 4.137 & 21.588 & 2,2 & 89,5 \\
\hline Западнобачка област & 37 & 188.087 & 5.083 & 2.420 & 1,5 & 77,7 \\
\hline Јужнобанатска област & 94 & 293.730 & 3.125 & 4.282 & 2,2 & 68,6 \\
\hline Јужнобачка област & 77 & 615.371 & 7.992 & 4.023 & 1,9 & 153,0 \\
\hline Севернобанатска област & 50 & 147.770 & 2.955 & 2.335 & 2,1 & 63,3 \\
\hline Севернобачка област & 45 & 186.906 & 4.153 & 1.784 & 2,5 & 104,8 \\
\hline Средњебанатска област & 55 & 187.667 & 3.412 & 3.257 & 1,7 & 57,6 \\
\hline Сремска област & 109 & 312.278 & 2.865 & 3.487 & 3,1 & 89,6 \\
\hline СРБИЈА - ЈУГ & 4.085 & 3.595 .613 & 880 & 52.676 & 7,8 & 68,3 \\
\hline РЕГИОН ШУМАДИЈЕ И ЗАПАДНЕ СРБИЈЕ & 2.112 & 2.031 .697 & 962 & 26.484 & 8,0 & 76,7 \\
\hline Златиборскаобласт & 439 & 286.549 & 653 & 6.147 & 7,1 & 46,6 \\
\hline Колубарска област & 218 & 174.513 & 801 & 2.467 & 8,8 & 70,7 \\
\hline Мачванскаобласт & 228 & 298.931 & 1.311 & 3.275 & 7,0 & 91,3 \\
\hline Моравичкаобласт & 206 & 212.603 & 1.032 & 3.036 & 6,8 & 70,0 \\
\hline Поморавскаобласт & 191 & 214.536 & 1.123 & 2.616 & 7,3 & 82,0 \\
\hline Расинскаобласт & 296 & 241.999 & 818 & 2.660 & 11,1 & 91,0 \\
\hline Рашкаобласт & 359 & 309.258 & 861 & 3.914 & 9,2 & 79,0 \\
\hline Шумадијскаобласт & 175 & 293.308 & 1.676 & 2.369 & 7,4 & 123,8 \\
\hline РЕГИОН ЈУЖНЕИ ИСТОЧНЕ СРБИЈЕ & 1973 & 1.563 .916 & 793 & 26.192 & 7,5 & 59,7 \\
\hline Борскаобласт & 90 & 124.992 & 1.389 & 3.505 & 2,6 & 35,7 \\
\hline Браничевскаобласт & 189 & 183.625 & 972 & 3.855 & 4,9 & 47,6 \\
\hline Зајечарскаобласт & 173 & 119.967 & 693 & 3.599 & 4,8 & 33,3 \\
\hline Јабланичкиаобласт & 336 & 216.304 & 644 & 2.769 & 12,1 & 78,1 \\
\hline Нишавскаобласт & 282 & 376.319 & 1.334 & 2.723 & 10,4 & 138,2 \\
\hline Пиротскаобласт & 214 & 92.479 & 432 & 2.762 & 7,7 & 33,5 \\
\hline Подунавскаобласт & 59 & 199.395 & 3.380 & 1.223 & 4,8 & 163,0 \\
\hline Пчињска област 1) & 363 & 159.081 & 438 & 3.526 & 10,3 & 45,1 \\
\hline Топличкаобласт & 267 & 91.754 & 344 & 2.230 & 12,0 & 41,1 \\
\hline
\end{tabular}

1) Обухвата само пописано становништво.

Уопштинама Прешево и Бујановац албанско

становништво није учествовало у Попису 2011. године.
Таб.2.

Основни показатељи насељености (стање 2011)

Tab. 2

Basic indicators of population (2011)

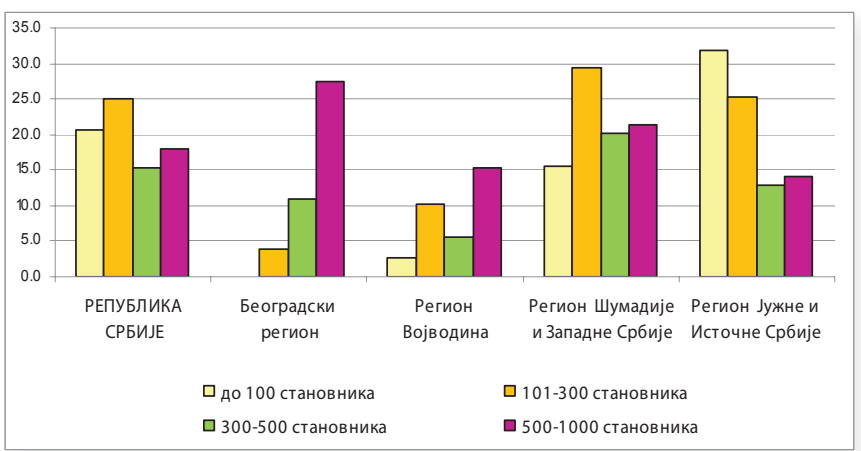

Графикон 2а.

Учешће насеља одређене величине у укупном броју насеља у региону - Попис 2011.

Graph 2a.

Share of settlement a certain size in the total number of settlements in the region - Census 2011

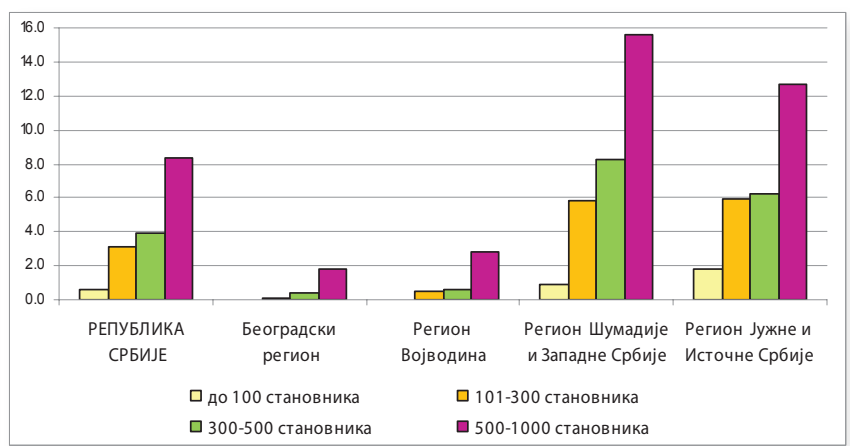

Графикон 26.

Учешће становника насеља одређене величине у укупном броју становника региона - Попис 2011.

Graph 2b.

Share of inhabitants in settlement a certain size in the total population of the region - Census 2011 


\begin{tabular}{|c|c|c|c|c|c|c|c|c|c|c|}
\hline \multirow{3}{*}{ Подручје } & \multirow{2}{*}{\multicolumn{2}{|c|}{ Укупно }} & \multicolumn{8}{|c|}{ Насеља према броју становника } \\
\hline & & & \multicolumn{2}{|c|}{$\begin{array}{c}\text { до } 100 \\
\text { становника }\end{array}$} & \multicolumn{2}{|c|}{$\begin{array}{c}101-300 \\
\text { становника }\end{array}$} & \multicolumn{2}{|c|}{$\begin{array}{c}300-500 \\
\text { становника }\end{array}$} & \multicolumn{2}{|c|}{$\begin{array}{c}500-1000 \\
\text { становника }\end{array}$} \\
\hline & $\begin{array}{c}\text { бр. } \\
\text { насеља }\end{array}$ & $\begin{array}{c}\text { бр.ста- } \\
\text { новника }\end{array}$ & $\begin{array}{c}\text { бр. } \\
\text { насеља }\end{array}$ & $\begin{array}{c}\text { бр.ста- } \\
\text { новника }\end{array}$ & \begin{tabular}{c|}
$6 p$. \\
насеља
\end{tabular} & $\begin{array}{c}\text { бр.ста- } \\
\text { новника }\end{array}$ & $\begin{array}{c}\text { бр. } \\
\text { насеља }\end{array}$ & $\begin{array}{c}\text { бр.ста- } \\
\text { новника }\end{array}$ & \begin{tabular}{c|} 
бр. \\
насеља
\end{tabular} & $\begin{array}{c}\text { бр.ста- } \\
\text { новника }\end{array}$ \\
\hline РЕПУБЛИКА СРБИЈЕ & 4709 & 7186862 & 966 & 46739 & 1176 & 224450 & 722 & 282763 & 843 & 598249 \\
\hline СРБИЈА - СЕВЕР & 624 & 3591249 & 12 & 824 & 53 & 10748 & 43 & 17644 & 115 & 84988 \\
\hline БЕОГРАДСКИ РЕГИОН & 157 & 1659440 & & & 6 & 1205 & 17 & 6901 & 43 & 30222 \\
\hline РЕГИОН ВОЈВОДИНА & 467 & 1931809 & 12 & 824 & 47 & 9543 & 26 & 10743 & 72 & 54766 \\
\hline Западнобачка област & 37 & 188087 & 0 & 0 & 0 & 0 & 2 & 831 & 0 & 0 \\
\hline Јужнобанатска област & 94 & 293730 & 5 & 281 & 15 & 3278 & 7 & 2783 & 16 & 12040 \\
\hline Јужнобачка област & 77 & 615371 & 1 & 100 & 3 & 662 & & & 9 & 7696 \\
\hline Севернобанатска област & 50 & 147770 & 1 & 94 & 11 & 1998 & 3 & 1153 & 7 & 5222 \\
\hline Севернобачка област & 45 & 186906 & 1 & 83 & 6 & 1088 & 6 & 2659 & 6 & 3505 \\
\hline Средњебанатска област & 55 & 187667 & 1 & 63 & 2 & 511 & 2 & 822 & 6 & 4148 \\
\hline Сремска област & 109 & 312278 & 3 & 203 & 10 & 2006 & 6 & 2495 & 28 & 22155 \\
\hline СРБИЈА - ЈУГ & 4085 & 3595613 & 954 & 45915 & 1123 & 213702 & 679 & 265119 & 728 & 513261 \\
\hline $\begin{array}{l}\text { РЕГИОН ШУМАДИЈЕ И ЗАПАДНЕ } \\
\text { СРБИЈЕ }\end{array}$ & 2112 & 2031697 & 330 & 17500 & 623 & 120191 & 425 & 167375 & 448 & 3156172 \\
\hline Златиборска област & 439 & 286549 & 113 & 5579 & 159 & 31177 & 76 & 29078 & 63 & 42852 \\
\hline Колубарска област & 218 & 174513 & 5 & 403 & 65 & 12227 & 76 & 30091 & 54 & 35982 \\
\hline Мачванска област & 228 & 298931 & 4 & 255 & 45 & 8951 & 47 & 18483 & 72 & 52709 \\
\hline Моравичка област & 206 & 212603 & 24 & 1707 & 70 & 13563 & 43 & 17159 & 41 & 29883 \\
\hline Поморавска област & 191 & 214536 & 13 & 625 & 43 & 8494 & 37 & 14585 & 59 & 42736 \\
\hline Расинска област & 296 & 241999 & 38 & 2069 & 86 & 16790 & 67 & 26541 & 68 & 46848 \\
\hline Рашка област & 359 & 309258 & 123 & 6249 & 113 & 20571 & 36 & 14084 & 39 & 27912 \\
\hline Шумадијска област & 175 & 293308 & 10 & 613 & 42 & 8418 & 43 & 17354 & 52 & 36695 \\
\hline РЕГИОН ЈУЖНЕИ ИСТОЧНЕ СРБИЈЕ & 1973 & 1563916 & 629 & 28530 & 500 & 93511 & 254 & 97744 & 280 & 197644 \\
\hline Борска област & 90 & 124992 & 3 & 199 & 15 & 3150 & 20 & 7863 & 36 & 25870 \\
\hline Браничевска област & 189 & 183625 & 5 & 240 & 41 & 8717 & 46 & 17817 & 61 & 42435 \\
\hline Зајечарска област & 173 & 119967 & 51 & 2529 & 66 & 12795 & 26 & 10029 & 16 & 10663 \\
\hline Јабланичкиа област & 336 & 216304 & 115 & 5657 & 85 & 15719 & 46 & 17859 & 55 & 37377 \\
\hline Нишавска област & 282 & 376319 & 39 & 2227 & 91 & 17859 & 53 & 20575 & 52 & 36829 \\
\hline Пиротска област & 214 & 92479 & 128 & 4898 & 54 & 9694 & 14 & 4858 & 8 & 5602 \\
\hline Подунавска област & 59 & 199395 & 0 & 0 & 2 & 422 & 4 & 1611 & 16 & 12793 \\
\hline Пчињска област 1) & 363 & 159081 & 140 & 6687 & 67 & 11185 & 22 & 8717 & 20 & 14405 \\
\hline Топличка област & 267 & 91754 & 143 & 5978 & 79 & 13970 & 23 & 8415 & 16 & 11670 \\
\hline
\end{tabular}

1) Обухвата само пописано становништво.

У општинама Прешево и Бујановац албанско

становништво није учествовало у Попису 2011. године.
Та6.3.

Број насеља и становника према величини насеља до 1000 становника - Попис 2011.

Tab. 3.

The number of settlements and population according to the size of settlement with 1000 inhabitans - Census 2011 области (62\% и 12\%). у Војводини је укупно 60, углавном у Јужнобанатској области (21 тј. 22\% насеља са 1,3\% становника) и Севернобанатској области (12, тј. 24\% насеља у којима живи око 1,4\% становништва ове области).

Насеља до 1.000 становника углавном карактерише исцрпљеност демографских потенцијала, како због негативног миграционог салда, тако и због недовољног биолошког обнављања, као и неповољна старосна структура, и то су главни фактори њиховог економског, социјалног и просторног пропадања, а код мањих насеља (до 100 становника) и њиховог опстанка. Истовремено, у овим насељима/селима, односно подручјима са интензивном депопулацијом, системски су "укорењени" неразвијеност, заосталост, сиромаштво и социјална искљученост. Услови живота у овим насељима били су деценијама потпуно запостављена тема у политичком, стручном и медијском дискурсу. Прво веће истраживање које је показало да је у Србији сиромаштво распрострањеније у сеоским подручјима у поређењу са градским насељима била је Анкета о животном стандарду становништва спроведена 2002. године (LSMS, 2002). Сличне резултате дају истраживања која се спроводе последњих година у циљу праћења Стратегије за смањење сиромаштва, као и друга наменска истраживања.

Дистрибуција насеља према величини (броју становника) и популацији која у њима живи дата је по регионима и областима у Табели 3, а њихово учешће по регионим на Графиконима 2a (учешће насеља) и 26 (учешће становника који у њима живе). 


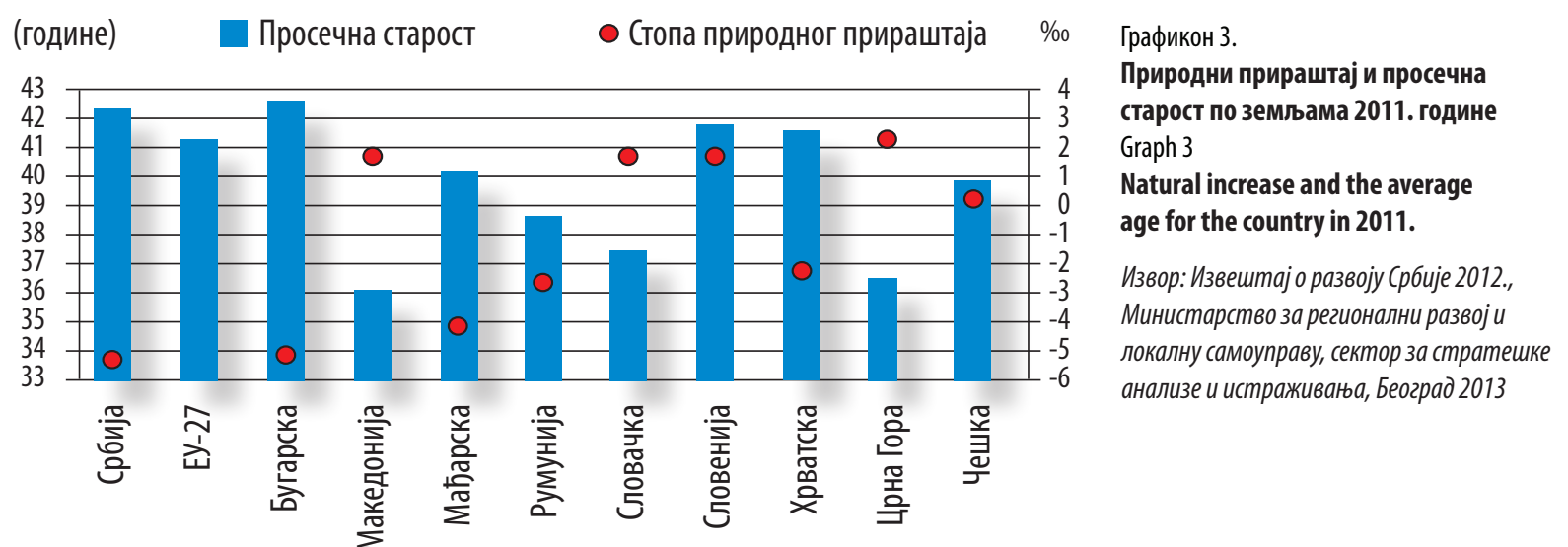

\section{СТАРЕњЕ СТАНОВНИШТВА}

Са просечном старошћу становништва од 42,2 године Србија спада у групу најстаријх земаља у Европи, поред Немачке (44,6), Италије $(43,5)$, Бугарске $(42,5)$, Грчке и Финске $(42,1)$. Регионалне разлике су велике. Најстарију популацију има Регион Јужне и Источне (рбије (43,3), затим регион Шумадије и Западне Србије (42,7), док је становништво Северног дела Србије нешто млађе од просека за Републику $(41,8)$. Србија је, слично Бугарској, у неповољнијој ситуацији у односу на поједине европске и суседне државе, због биолошке депопулације (висока вредност негативног природног прираштаја), која убрзава процес старења (Графикон 3).

Интензивна емиграциона кретања, смањење наталитета (константан негативан природни прираштај), као и процес старења, одразили су се на промене укупних потенцијала становништва по великим старосним групама на подручју Србије. Смањење броја становника забележено је у млађим старосним групама: старосној групи 0-19 година за око 15\% (са 1.672.421 на 1.427.272) и 20-39 година за око 5\% (са 1.979 .451 на 1.910.323), а повећање у старости 40-64 године за око 28\% (са 2.025.875 на 2.2917.163 лица) и незнатно у старости изнад 65 година (са 1.240.505 на 1.250.316 лица).

Овако велико смањење броја младог становништва директан је одговор на процесе из последње деценије 20. века, првенствено исељавање становништва (по проценама током 90-их година прошлог века из земље се иселило између сто хиљада и триста хиљада лица) и константно опадање наталитета. Потенцијали ове старосне групе на Северу Србије смањили су се за око 12\% (са 551.139 на 510.200), а на Југу (рбије чак за 22\% (са 882.091 на 722.712).

Стање потенцијала по великим старосним групама и достигнути ниво старења још су израженији на нивоу ужих просторних целина и према типовима насеља.

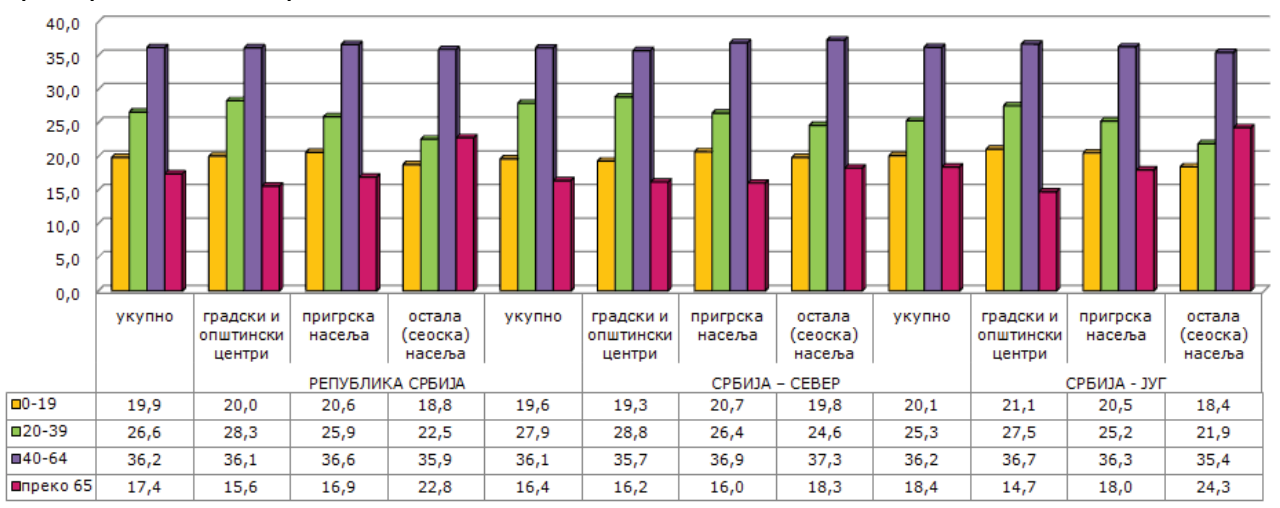

\section{Старосна структура становништва по областима и према типу насеља}

За потребе овог истраживања урађена је класификација (условна подела) насеља према типу у три категорије: 1) градска насеља и општински центри, 2) приградска насеља и 3) сеоска насеља. У прву групу сврстана су насеља која имају административни статус градског насеља (насеља са статусом града, градска насеља, као и насеља која имају функцију општинског центра, немају статус градског насеља, а у статистици су сврстана у групу „остала насеља"). У другу групу су укључена насеља, односно катастарске општине, директно/територијално повезана са градским/општинским центром. Према многим обележјима, а пре свега условима привређивања и квалитета живота (посебно у погледу доступности услуга од јавног интереса) битно се разликују од сеоских, нарочито оних у рубним зонама општина. Неретко, ова насеља чине део континуално изграђеног градског ткива. У трећој групи остају сеоска насеља, која су нарочито у целини Србија - Југ често изолована и неинтегрисана у мрежу насеља.

Уз сав ризик који носи оваква класификација, она пружа бољи увид у разлике које постоје између овако груписаних/ класификованих насеља у неким битним демографским и социоекономским обележјима.

Посматрано у апсолутним бројевима, према званичној статистичкој подели, у градским насељима живи 4.271.872 $(59,4 \%)$, а у осталим $2.914 .990(40,6 \%)$ становника. Према модификованој класификацији, у градским насељима и општинским центрима живи 4.336 .873 (60,3\%), приградским $1.254 .381(17,5 \%)$, а у сеоским $1.595 .638(22,2 \%)$ становника Србије.
Графикон 4.

Учешће становништва по великим старосним групама на нивоу функционалних целина и према типу насеља Попис 2011. године Graph 4 The major age population groups share by the level of functional units and by the type of settlement Census 2011. 
Tаб. 4.

Становништво према старосним групама по регионима и областима - Попис 2011.

Tab. 4

The population according to age groups, regions and districts - Census 2011.

\begin{tabular}{|c|c|c|c|c|c|c|c|c|c|c|c|}
\hline \multirow[b]{2}{*}{ Подручје } & & \multirow{2}{*}{$\begin{array}{c}\text { Укупан } \\
\text { број } \\
\text { становника }\end{array}$} & \multicolumn{4}{|c|}{ број становника по старосним групама } & \multicolumn{4}{|c|}{ Учешће у укупном становништву } & \multirow{2}{*}{$\begin{array}{l}\text { Индекс } \\
\text { старења* }\end{array}$} \\
\hline & & & $0-19$ & $20-39$ & $40-64$ & $\begin{array}{c}\text { преко } 65 \\
\text { година }\end{array}$ & $0-19$ & $20-39$ & $40-64$ & $\begin{array}{c}\text { преко } 65 \\
\text { година }\end{array}$ & \\
\hline \multirow{4}{*}{ РЕПУБЛИКА СРБИЈА } & укупно & 7186862 & 1427272 & 1910323 & 2598951 & 1250316 & 19.9 & 26.6 & 36.2 & 17.4 & 1.3 \\
\hline & гоц & 4336843 & 869119 & 1225802 & 1566776 & 675146 & 20.0 & 28.3 & 36.1 & 15.6 & 1.0 \\
\hline & Пн & 1254381 & 258417 & 324714 & 459339 & 211911 & 20.6 & 25.9 & 36.6 & 16.9 & 1.2 \\
\hline & OCH & 1595638 & 299736 & 359807 & 572836 & 363259 & 18.8 & 22.5 & 35.9 & 22.8 & 1.7 \\
\hline \multirow{4}{*}{ СРБИЈА - СЕВЕР } & укупно & 3591249 & 704560 & 1001463 & 1296926 & 588300 & 19.6 & 27.9 & 36.1 & 16.4 & 1.2 \\
\hline & гоц & 2502662 & 482801 & 721171 & 893726 & 404964 & 19.3 & 28.8 & 35.7 & 16.2 & 1.2 \\
\hline & $\Pi H$ & 690029 & 142675 & 182259 & 254556 & 110539 & 20.7 & 26.4 & 36.9 & 16.0 & 1.0 \\
\hline & $\mathrm{OCH}$ & 398558 & 79084 & 98033 & 148644 & 72797 & 19.8 & 24.6 & 37.3 & 18.3 & 1.3 \\
\hline \multirow{4}{*}{ Београдски регион } & укупно & 1659440 & 317258 & 480188 & 590232 & 271762 & 19.1 & 28.9 & 35.6 & 16.4 & 1.2 \\
\hline & гОЦ & 1344844 & 252062 & 394649 & 476100 & 222033 & 18.7 & 29.3 & 35.4 & 16.5 & 1.3 \\
\hline & $\Pi H$ & 220130 & 46505 & 62351 & 79391 & 31883 & 21.1 & 28.3 & 36.1 & 14.5 & 1.0 \\
\hline & $\mathrm{OCH}$ & 94466 & 18691 & 23188 & 34741 & 17846 & 19.8 & 24.5 & 36.8 & 18.9 & 1.3 \\
\hline \multirow{4}{*}{ Регион Војводине } & укупно & 1931809 & 387302 & 521275 & 706694 & 316538 & 20.0 & 27.0 & 36.6 & 16.4 & 1.2 \\
\hline & гоц & 1157818 & 230739 & 326522 & 417626 & 182931 & 19.9 & 28.2 & 36.1 & 15.8 & 1.2 \\
\hline & $\Pi H$ & 469899 & 96170 & 119908 & 175165 & 78656 & 20.5 & 25.5 & 37.3 & 16.7 & 1.2 \\
\hline & $\mathrm{OCH}$ & 304092 & 60393 & 74845 & 113903 & 54951 & 19.9 & 24.6 & 37.5 & 18.1 & 1.3 \\
\hline \multirow{4}{*}{ Западнобачка област } & укупно & 188087 & 35244 & 47401 & 70972 & 34470 & 18.7 & 25.2 & 37.7 & 18.3 & 1.4 \\
\hline & ГОЦ & 100712 & 19280 & 26267 & 37544 & 17621 & 19.1 & 26.1 & 37.3 & 17.5 & 1.3 \\
\hline & $\Pi \mathrm{H}$ & 59343 & 10848 & 14396 & 22830 & 11269 & 18.3 & 24.3 & 38.5 & 19.0 & 1.5 \\
\hline & $\mathrm{OCH}$ & 28032 & 5116 & 6738 & 10598 & 5580 & 18.3 & 24.0 & 37.8 & 19.9 & 1.5 \\
\hline & укупно & 293730 & 59237 & 77493 & 108556 & 48444 & 20.2 & 26.4 & 37.0 & 16.5 & 1.2 \\
\hline Јужнобанатска обпаст & гОЦ & 168286 & 33064 & 46341 & 62473 & 26408 & 19.6 & 27.5 & 37.1 & 15.7 & 1.2 \\
\hline 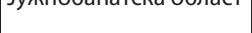 & $\Pi \mathrm{H}$ & 60633 & 13103 & 15142 & 22070 & 10318 & 21.6 & 25.0 & 36.4 & 17.0 & 1.1 \\
\hline & $\mathrm{OCH}$ & 64811 & 13070 & 16010 & 24013 & 11718 & 20.2 & 24.7 & 37.1 & 18.1 & 1.3 \\
\hline & укупно & 615371 & 127795 & 179193 & 216223 & 92160 & 20.8 & 29.1 & 35.1 & 15.0 & 1.1 \\
\hline Јужнобачка обпаст & гОЦ & 433723 & 88748 & 131053 & 149621 & 64301 & 20.5 & 30.2 & 34.5 & 14.8 & 1.1 \\
\hline ЈУЖНООवपК ООЛवС & $\Pi \mathrm{H}$ & 144883 & 31382 & 38767 & 53034 & 21700 & 21.7 & 26.8 & 36.6 & 15.0 & 1.0 \\
\hline & $\mathrm{OCH}$ & 36765 & 7665 & 9373 & 13568 & 6159 & 20.8 & 25.5 & 36.9 & 16.8 & 1.1 \\
\hline & укупно & 147770 & 29120 & 37442 & 55004 & 26204 & 19.7 & 25.3 & 37.2 & 17.7 & 1.3 \\
\hline Севернобанатска & гОЦ & 93201 & 17995 & 24427 & 34697 & 16082 & 19.3 & 26.2 & 37.2 & 17.3 & 1.3 \\
\hline област & $\Pi \mathrm{H}$ & 34936 & 7080 & 8299 & 13026 & 6531 & 20.3 & 23.8 & 37.3 & 18.7 & 1.3 \\
\hline & $\mathrm{OCH}$ & 19633 & 4045 & 4716 & 7281 & 3591 & 20.6 & 24.0 & 37.1 & 18.3 & 1.2 \\
\hline & укупно & 186906 & 36975 & 49980 & 67978 & 31973 & 19.8 & 26.7 & 36.4 & 17.1 & 1.2 \\
\hline Севернобачка обдаст & гОЦ & 125144 & 24999 & 34560 & 44927 & 20658 & 20.0 & 27.6 & 35.9 & 16.5 & 1.2 \\
\hline Севернобачка област & $\Pi \mathrm{H}$ & 37454 & 7037 & 9229 & 14275 & 6913 & 18.8 & 24.6 & 38.1 & 18.5 & 1.3 \\
\hline & $\mathrm{OCH}$ & 24308 & 4939 & 6191 & 8776 & 4402 & 20.3 & 25.5 & 36.1 & 18.1 & 1.2 \\
\hline & укупно & 187667 & 37390 & 47638 & 70520 & 32119 & 19.9 & 25.4 & 37.6 & 17.1 & 1.2 \\
\hline Средњобанатска & ГОЦ & 98536 & 19458 & 26116 & 36837 & 16125 & 19.7 & 26.5 & 37.4 & 16.4 & 1.2 \\
\hline област & $\Pi \mathrm{H}$ & 51546 & 10357 & 12606 & 19574 & 9009 & 20.1 & 24.5 & 38.0 & 17.5 & 1.2 \\
\hline & $\mathrm{OCH}$ & 37585 & 7575 & 8916 & 14109 & 6985 & 20.2 & 23.7 & 37.5 & 18.6 & 1.2 \\
\hline & укупно & 312278 & 61541 & 82128 & 117441 & 51168 & 19.7 & 26.3 & 37.6 & 16.4 & 1.2 \\
\hline Сремска област & гОЦ & 138216 & 27195 & 37758 & 51527 & 21736 & 19.7 & 27.3 & 37.3 & 15.7 & 1.2 \\
\hline 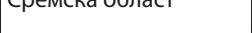 & $\Pi \mathrm{H}$ & 81104 & 16363 & 21469 & 30356 & 12916 & 20.2 & 26.5 & 37.4 & 15.9 & 1.1 \\
\hline & $\mathrm{OCH}$ & 92958 & 17983 & 22901 & 35558 & 16516 & 19.3 & 24.6 & 38.3 & 17.8 & 1.3 \\
\hline & укупно & 3595613 & 722712 & 908860 & 1302025 & 662016 & 20.1 & 25.3 & 36.2 & 18.4 & 1.3 \\
\hline СРБИЈА - ЈУГ & гоц & 1834181 & 386318 & 504631 & 673050 & 270182 & 21.1 & 27.5 & 36.7 & 14.7 & 1.0 \\
\hline 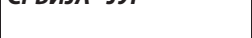 & $\Pi H$ & 564352 & 115742 & 142455 & 204783 & 101372 & 20.5 & 25.2 & 36.3 & 18.0 & 1.2 \\
\hline & $\mathrm{OCH}$ & 1197080 & 220652 & 261774 & 424192 & 290462 & 18.4 & 21.9 & 35.4 & 24.3 & 1.7 \\
\hline & укупно & 2031697 & 415805 & 518975 & 737907 & 359010 & 20.5 & 25.5 & 36.3 & 17.7 & 1.2 \\
\hline Регион Шумадије и & гоц & 997590 & 211697 & 275524 & 366040 & 144329 & 21.2 & 27.6 & 36.7 & 14.5 & 1.0 \\
\hline Западне Србије & $\Pi H$ & 309255 & 65934 & 80197 & 112538 & 50586 & 21.3 & 25.9 & 36.4 & 16.4 & 1.1 \\
\hline & $\mathrm{OCH}$ & 724852 & 138174 & 163254 & 259329 & 164095 & 19.1 & 22.5 & 35.8 & 22.6 & 1.6 \\
\hline & укупно & 286549 & 58263 & 71547 & 106394 & 50345 & 20.3 & 25.0 & 37.1 & 17.6 & 1.2 \\
\hline Златибопска обдаст & гОц & 150065 & 32048 & 40781 & 56847 & 20389 & 21.4 & 27.2 & 37.9 & 13.6 & 1.0 \\
\hline 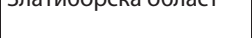 & $\Pi \mathrm{H}$ & 44854 & 9501 & 11540 & 16703 & 7110 & 21.2 & 25.7 & 37.2 & 15.9 & 1.1 \\
\hline & $\mathrm{OCH}$ & 91630 & 16714 & 19226 & 32844 & 22846 & 18.2 & 21.0 & 35.8 & 24.9 & 1.8 \\
\hline & укупно & 174513 & 33168 & 43189 & 65033 & 33123 & 19.0 & 24.7 & 37.3 & 19.0 & 1.4 \\
\hline Копубапскаобпаст & гОЦ & 76262 & 14725 & 21102 & 29131 & 11304 & 19.3 & 27.7 & 38.2 & 14.8 & 1.1 \\
\hline 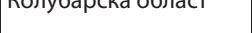 & $\Pi \mathrm{H}$ & 29878 & 6022 & 7609 & 11227 & 5020 & 20.2 & 25.5 & 37.6 & 16.8 & 1.2 \\
\hline & $\mathrm{OCH}$ & 68373 & 12421 & 14478 & 24675 & 16799 & 18.2 & 21.2 & 36.1 & 24.6 & 1.7 \\
\hline & укупно & 298931 & 60456 & 76304 & 112018 & 50153 & 20.2 & 25.5 & 37.5 & 16.8 & 1.2 \\
\hline Мачванска област & гоц & 103379 & 20758 & 28128 & 39257 & 15236 & 20.1 & 27.2 & 38.0 & 14.7 & 1.1 \\
\hline ТІачванска ооласт & $\Pi \mathrm{H}$ & 69061 & 14351 & 18272 & 25908 & 10530 & 20.8 & 26.5 & 37.5 & 15.2 & 1.1 \\
\hline & $\mathrm{OCH}$ & 126491 & 25347 & 29904 & 46853 & 24387 & 20.0 & 23.6 & 37.0 & 19.3 & 1.3 \\
\hline
\end{tabular}


Весна Јокић, АУз8/2013/страна 17-32/Просторни размештај и старосна структура становништва као фактор ограничења развоја Србије

\begin{tabular}{|c|c|c|c|c|c|c|c|c|c|c|c|}
\hline \multirow[b]{2}{*}{ Подручје } & & \multirow{2}{*}{$\begin{array}{c}\text { Укупан } \\
\text { број } \\
\text { становника }\end{array}$} & \multicolumn{4}{|c|}{ број становника по старосним групама } & \multicolumn{4}{|c|}{ Учешће у укупном становништву } & \multirow{2}{*}{$\begin{array}{l}\text { Индекс } \\
\text { старења* }\end{array}$} \\
\hline & & & $0-19$ & $20-39$ & $40-64$ & $\begin{array}{c}\text { преко } 65 \\
\text { година }\end{array}$ & $0-19$ & $20-39$ & $40-64$ & $\begin{array}{c}\text { преко } 65 \\
\text { година }\end{array}$ & \\
\hline \multirow{4}{*}{ Моравичка област } & укупно & 212603 & 40474 & 53549 & 78527 & 40053 & 19.0 & 25.2 & 36.9 & 18.8 & 1.4 \\
\hline & ГОЦ & 114404 & 23067 & 31787 & 42653 & 16897 & 20.2 & 27.8 & 37.3 & 14.8 & 1.1 \\
\hline & $\Pi \mathrm{H}$ & 17626 & 3401 & 4477 & 6657 & 3091 & 19.3 & 25.4 & 37.8 & 17.5 & 1.3 \\
\hline & $\mathrm{OCH}$ & 80573 & 14006 & 17285 & 29217 & 20065 & 17.4 & 21.5 & 36.3 & 24.9 & 1.8 \\
\hline \multirow{4}{*}{ Поморавска област } & укупно & 214536 & 41120 & 51701 & 77353 & 44362 & 19.2 & 24.1 & 36.1 & 20.7 & 1.4 \\
\hline & гОЦ & 98874 & 20152 & 26017 & 36190 & 16515 & 20.4 & 26.3 & 36.6 & 16.7 & 1.2 \\
\hline & $\Pi \mathrm{H}$ & 39015 & 7811 & 9441 & 14092 & 7671 & 20.0 & 24.2 & 36.1 & 19.7 & 1.4 \\
\hline & $\mathrm{OCH}$ & 76647 & 13157 & 16243 & $2707 \overline{1}$ & 20176 & 17.2 & 21.2 & 35.3 & 26.3 & 2.0 \\
\hline \multirow{4}{*}{ Расинска област } & укупно & 241999 & 46194 & 59717 & 89249 & 46839 & 19.1 & 24.7 & 36.9 & 19.4 & 1.4 \\
\hline & ГОЦ & 91727 & 18339 & 24705 & 34262 & 14421 & 20.0 & 26.9 & 37.4 & 15.7 & 1.2 \\
\hline & $\Pi \mathrm{H}$ & 27477 & 5618 & 7206 & 10174 & 4479 & 20.4 & 26.2 & 37.0 & 16.3 & 1.2 \\
\hline & $\mathrm{OCH}$ & 122795 & 22237 & 27806 & 44813 & 27939 & 18.1 & 22.6 & 36.5 & 22.8 & 1.8 \\
\hline \multirow{4}{*}{ Рашка област } & укупно & 309258 & 79257 & 85206 & 100585 & 44210 & 25.6 & 27.6 & 32.5 & 14.3 & 0.8 \\
\hline & ГОЦ & 164543 & 43409 & 47192 & 53635 & 20307 & 26.4 & 28.7 & 32.6 & 12.3 & 0.7 \\
\hline & $\Pi \mathrm{H}$ & 46492 & 12416 & 13048 & 14926 & 6102 & 26.7 & 28.1 & 32.1 & 13.1 & 0.7 \\
\hline & $\mathrm{OCH}$ & 98223 & 23432 & 24966 & 32024 & 17801 & 23.9 & 25.4 & 32.6 & 18.1 & 0.8 \\
\hline \multirow{4}{*}{ Шумадијска област } & укупно & 293308 & 56873 & 77762 & 108748 & 49925 & 19.4 & 26.5 & 37.1 & 17.0 & 1.3 \\
\hline & ГОЦ & 198336 & 39199 & 55812 & 74065 & 29260 & 19.8 & 28.1 & 37.3 & 14.8 & 1.1 \\
\hline & $\Pi \mathrm{H}$ & 34852 & 6814 & 8604 & 12851 & 6583 & 19.6 & 24.7 & 36.9 & 18.9 & 1.4 \\
\hline & $\mathrm{OCH}$ & 60120 & 10860 & 13346 & 21832 & 14082 & 18.1 & 22.2 & 36.3 & 23.4 & 1.7 \\
\hline \multirow{4}{*}{$\begin{array}{l}\text { Регион Јужне и } \\
\text { Источне Србије }\end{array}$} & укупно & 1563916 & 306907 & 389885 & 564118 & 303006 & 19.6 & 24.9 & 36.1 & 19.4 & 1.4 \\
\hline & гоц & 836591 & 174621 & 229107 & 307010 & 125853 & 20.9 & 27.4 & 36.7 & 15.0 & 1.1 \\
\hline & $\Pi H$ & 255097 & 49808 & 62258 & 92245 & 50786 & 19.5 & 24.4 & 36.2 & 19.9 & 1.4 \\
\hline & $\mathrm{OCH}$ & 472228 & 82478 & 98520 & 164863 & 126367 & 17.5 & 20.9 & 34.9 & 26.8 & 2.0 \\
\hline \multirow{4}{*}{ Борска област } & укупно & 124992 & 22616 & 29023 & 47459 & 25894 & 18.1 & 23.2 & 38.0 & 20.7 & 1.6 \\
\hline & ГОЦ & 70880 & 14410 & 18782 & 27883 & 9805 & 20.3 & 26.5 & 39.3 & 13.8 & 1.1 \\
\hline & $\Pi \mathrm{H}$ & 17603 & 2864 & 3612 & 6551 & 4576 & 16.3 & 20.5 & 37.2 & 26.0 & 2.2 \\
\hline & $\mathrm{OCH}$ & 36509 & 5342 & 6629 & 13025 & 11513 & 14.6 & 18.2 & 35.7 & 31.5 & 2.8 \\
\hline & укупно & 183625 & 35733 & 43493 & 65334 & 39065 & 19.5 & 23.7 & 35.6 & 21.3 & 1.5 \\
\hline & гОЦ & 77109 & 16398 & 20696 & 27919 & 12096 & 21.3 & 26.8 & 36.2 & 15.7 & 1.1 \\
\hline ьраничевска област & $\Pi \mathrm{H}$ & 22707 & 4285 & 4882 & 8029 & 5511 & 18.9 & 21.5 & 35.4 & 24.3 & 1.7 \\
\hline & $\mathrm{OCH}$ & 83809 & 15050 & 17915 & 29386 & 21458 & 18.0 & 21.4 & 35.1 & 25.6 & 1.8 \\
\hline & укупно & 119967 & 19631 & 26602 & 44741 & 28993 & 16.4 & 22.2 & 37.3 & 24.2 & 2.0 \\
\hline & ГОЦ & 69035 & 12798 & 17776 & 26635 & 11826 & 18.5 & 25.7 & 38.6 & 17.1 & 1.4 \\
\hline зајечарска област & $\Pi \mathrm{H}$ & 16659 & 2612 & 3524 & 6179 & 4344 & 15.7 & 21.2 & 37.1 & 26.1 & 1.8 \\
\hline & $\mathrm{OCH}$ & 34273 & 4221 & 5302 & 11927 & 12823 & 12.3 & 15.5 & 34.8 & 37.4 & 3.9 \\
\hline & укупно & 216304 & 44780 & 54652 & 76872 & 40000 & 20.7 & 25.3 & 35.5 & 18.5 & 1.2 \\
\hline Јабланичка област & ГОЦ & 97213 & 21327 & 26757 & 35322 & 13807 & 21.9 & 27.5 & 36.3 & 14.2 & 1.0 \\
\hline Јалланичка ооласт & $\Pi \mathrm{H}$ & 30535 & 6500 & 7633 & 10896 & 5506 & 21.3 & 25.0 & 35.7 & 18.0 & 1.2 \\
\hline & $\mathrm{OCH}$ & 88556 & 16953 & 20262 & 30654 & 20687 & 19.1 & 22.9 & 34.6 & 23.4 & 1.6 \\
\hline & укупно & 376319 & 72043 & 98895 & 133818 & 71563 & 19.1 & 26.3 & 35.6 & 19.0 & 1.4 \\
\hline Нишавска област & гОЦ & 218105 & 42927 & 61773 & 77960 & 35445 & 19.7 & 28.3 & 35.7 & 16.3 & 1.2 \\
\hline & $\Pi \mathrm{H}$ & 94859 & 18495 & 24310 & 34166 & 17888 & 19.5 & 25.6 & 36.0 & 18.9 & 1.4 \\
\hline & $\mathrm{OCH}$ & 63355 & 10621 & 12812 & 21692 & 18230 & 16.8 & 20.2 & 34.2 & 28.8 & 2.2 \\
\hline & укупно & 92479 & 15921 & 21578 & 34217 & 20763 & 17.2 & 23.3 & 37.0 & 22.5 & 1.8 \\
\hline Пиротска обпаст & гОЦ & 57807 & 11295 & 15185 & 21945 & 9382 & 19.5 & 26.3 & 38.0 & 16.2 & 1.2 \\
\hline 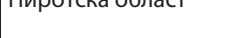 & $\Pi \mathrm{H}$ & 15376 & 2636 & 3618 & 5911 & 3211 & 17.1 & 23.5 & 38.4 & 20.9 & 1.7 \\
\hline & $\mathrm{OCH}$ & 19296 & 1990 & $277 \overline{5}$ & 6361 & 8170 & 10.3 & 14.4 & 33.0 & 42.3 & 5.0 \\
\hline & укупно & 199395 & 41672 & 51773 & 72900 & 33050 & 20.9 & 26.0 & 36.6 & 16.6 & 1.2 \\
\hline Попунавска обпаст & гОЦ & 103864 & 21982 & 28419 & 38232 & 15231 & 21.2 & 27.4 & 36.8 & 14.7 & 1.0 \\
\hline Подунавска област & $\Pi \mathrm{H}$ & 27402 & 6017 & 7063 & 9926 & 4396 & 22.0 & 25.8 & 36.2 & 16.0 & 1.1 \\
\hline & $\mathrm{OCH}$ & 68129 & 13673 & 16291 & 24742 & 13423 & 20.1 & 23.9 & 36.3 & 19.7 & 1.4 \\
\hline & укупно & 159081 & 35461 & 42095 & 56569 & 24956 & 22.3 & 26.5 & 35.6 & 15.7 & 1.0 \\
\hline Пчињска област & ГОЦ & 93316 & 21926 & 26331 & 33556 & 11503 & 23.5 & 28.2 & 36.0 & 12.3 & 0.8 \\
\hline І ЧИҢСКа ООЛАСт & $\Pi \mathrm{H}$ & 17089 & 3783 & 4588 & 6106 & 2612 & 22.1 & 26.8 & 35.7 & 15.3 & 1.0 \\
\hline & $\mathrm{OCH}$ & 48676 & 9752 & 11176 & 16907 & 10841 & 20.0 & 23.0 & 34.7 & 22.3 & 1.4 \\
\hline & укупно & 91754 & 19050 & 21774 & 32208 & 18722 & 20.8 & 23.7 & 35.1 & 20.4 & 1.3 \\
\hline Топпичка обпаст & ГОЦ & 49262 & 11558 & 13388 & 17558 & 6758 & 23.5 & 27.2 & 35.6 & 13.7 & 0.9 \\
\hline 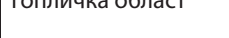 & $\Pi \mathrm{H}$ & 12867 & 2616 & 3028 & 4481 & 2742 & 20.3 & 23.5 & 34.8 & 21.3 & 1.4 \\
\hline & $\mathrm{OCH}$ & 29625 & 4876 & 5358 & 10169 & 9222 & 16.5 & 18.1 & 34.3 & 31.1 & 2.4 \\
\hline
\end{tabular}

ГОЦ - градскии општински центри; ПН - приградска насеља; ОСН - остала (сеоска) насеља

* индекс старења - однос становништва са 60 и више година и становништва до 19 година.

Старосна структура становништва Републике и две функционалне целине дата је према типу насеља на Графикону 4, а по регионима и областима у Табели 4.

На подручју Републике, 2011. године, младо становништво (до 19 година) чинило је петину од укупног становништва, са сличним учешћем у градским и општинским центрима и приградским насељима $(20,0 \%$ и 20,6\%), али већим него у сеоским насељима (18,8\%). Млађе средовечно становништво (20-39 година) било је заступљено са 26,6\% и са знатно већим учешћем у градским и општинским центрима $(28,3 \%)$ и приградским насељима $(25,9 \%)$ него у сеоским насељима $(22,5 \%)$, док је старије средовечно становништво (40-64 године) било најбројније - 36,2\% и са сличним учешћима у свим насељима. Становништво старије од 65 година је учествовало са 17,4\%, а разлика између градских и општинских центара и приградских и сеоских насеља је већ веома велика (15,6\% : 16,9\%: 22,8\%).

у целини Србија-Север учешћа старосних група су слична 
као у Републици, са мањим разликама међу различитим типовима насеља, док су у целини (рбија-Југ разлике у учешћима младог и најстаријег становништва између градских и општинксих центара, приградских и сеоских насеља веома велике, посебно код старије популације. Тако је, 2011. године, око четвртине становништва у селима $(24,3 \%)$ било старије од 65 година (у градским/општинским центрима 14,7\%, у приградским насељима 18,0\%).

Регион Шумадија и Поморавље има нешто „млађу” популацију и са мањим разликама у учешћу појединих старосних контингената у различитим типовима насеља у односу на регион Јужне и Источне Србије. У овом региону најстарију популацију имају Поморавска област (индекс старења 1,4, у селима 2,0 и учешће становништва са 65 и више година 26,3\%), Моравичка, Колубарска и Расинска област са индексима старења од 1,4 и сеоским насељима 1,8 и 1,7 (учешће старог становништва око 25\%). Најмлађе становништво, не само у региону, већ и у Републици, има Рашка област - индекс старења 0,8 (учешће младог становништва 25,6\%, старог 14,3\%), у градским/општинским центрима и приградским насељима 0,7 и селима 0,8 (однос младог и старог становништва $1,3: 1,0)$.

Најстарију популацију и највеће диспропорције у просторном размештају, првенствено младог становништва, има регион Јужне и Источне Србије. Старосна структура, односно

Ta6.5.

Насеља до 100 становника

Tab. 5.

Settlements up to 100 inhabitants

\begin{tabular}{|c|c|c|c|c|c|c|c|c|c|c|c|c|c|c|c|c|c|c|}
\hline \multirow{3}{*}{ Подручје } & \multicolumn{2}{|c|}{ Број насеља } & \multirow{2}{*}{\multicolumn{6}{|c|}{$\begin{array}{l}\text { Број насеља према учешћу } \\
\text { становништва старијег од } 65 \text { година }\end{array}$}} & \multirow{2}{*}{\multicolumn{5}{|c|}{$\begin{array}{l}\text { Број насеља према броју деце до } \\
14 \text { година }\end{array}$}} & \multirow{2}{*}{\multicolumn{5}{|c|}{$\begin{array}{c}\text { Број насеља према учешћу млађе женске } \\
\text { фертилне популације (20-39 година) }\end{array}$}} \\
\hline & \multirow[b]{2}{*}{ Укупна } & \multirow{2}{*}{$\begin{array}{c}\text { до } 100 \\
\text { станов- } \\
\text { ника }\end{array}$} & & & & & & & & & & & & & & & & \\
\hline & & & $100 \%$ & $\begin{array}{c}\text { преко } \\
75 \%\end{array}$ & $\begin{array}{c}50- \\
75 \%\end{array}$ & $\begin{array}{l}30- \\
50 \%\end{array}$ & $\begin{array}{c}20- \\
30 \%\end{array}$ & $\begin{array}{l}\text { мање } \\
\text { од } 20\end{array}$ & $\begin{array}{c}\text { без } \\
\text { деце }\end{array}$ & $\begin{array}{c}1 \\
\text { дете }\end{array}$ & $2-5$ & $\begin{array}{l}6- \\
10\end{array}$ & $\begin{array}{c}11 \text { n } \\
\text { више }\end{array}$ & без & $\begin{array}{c}1 \\
\text { жена }\end{array}$ & $2-5$ & $6-10$ & 11 и више \\
\hline $\begin{array}{l}\text { РЕПУБЛИКА } \\
\text { СРБИЈЕ }\end{array}$ & 4709 & 966 & 18 & 86 & 233 & 377 & 135 & 117 & 330 & 91 & 277 & 142 & 134 & 280 & 153 & 320 & 148 & 190 \\
\hline СРБИЈА- СЕВЕР & 624 & 12 & 0 & 0 & 0 & 2 & 6 & 4 & 0 & & & & & 0 & 1 & 4 & 6 & 1 \\
\hline Београдски регион & 157 & 0 & & & & & 0 & 0 & & & & & & & & & & \\
\hline Регион Војводина & 467 & 12 & 0 & 0 & 0 & 2 & 6 & 4 & 2 & & 4 & 2 & & & 1 & 4 & 6 & 1 \\
\hline СРБИЈА-ЈУГ & 4085 & 954 & 18 & 86 & 233 & 375 & 129 & 113 & 328 & 91 & 273 & 140 & 122 & 280 & 152 & 316 & 142 & 64 \\
\hline $\begin{array}{l}\text { РегионШумадије и } \\
\text { Западне Србије }\end{array}$ & 2112 & 330 & 1 & 16 & 45 & 114 & 72 & 82 & 63 & 23 & 98 & 57 & 89 & 57 & 34 & 134 & 86 & 19 \\
\hline $\begin{array}{l}\text { РегионЈужне и } \\
\text { Источне Србије }\end{array}$ & 1973 & 624 & 17 & 70 & 188 & 261 & 57 & 31 & 265 & 68 & 175 & 83 & 33 & 223 & 118 & 182 & 56 & 45 \\
\hline
\end{tabular}

Таб. 6.

Насеља од 100 до 300 становника

Tab. 6.

Settlements of 100 to 300 inhabitants

\begin{tabular}{|c|c|c|c|c|c|c|c|c|c|c|c|c|c|c|c|c|}
\hline \multirow{2}{*}{ Подручје } & \multicolumn{2}{|c|}{ Број насеља } & \multicolumn{4}{|c|}{$\begin{array}{c}\text { Број насеља према учешћу } \\
\text { становништва старијег од } 65 \\
\text { година }\end{array}$} & \multicolumn{5}{|c|}{$\begin{array}{c}\text { Број насеља према броју деце до } 14 \\
\text { година }\end{array}$} & \multicolumn{5}{|c|}{$\begin{array}{c}\text { Број насеља према учешћу млађе } \\
\text { женске фертилне популације (20-39 } \\
\text { година) }\end{array}$} \\
\hline & Укупна & $\begin{array}{l}101-300 \\
\text { станов- } \\
\text { ника }\end{array}$ & $\begin{array}{c}50- \\
75 \%\end{array}$ & $\begin{array}{c}30- \\
50 \%\end{array}$ & $\begin{array}{c}20- \\
30 \%\end{array}$ & $\begin{array}{l}\text { мање } \\
\text { од } 20\end{array}$ & $\begin{array}{l}\text { без } \\
\text { деце }\end{array}$ & $\begin{array}{c}1 \\
\text { дете }\end{array}$ & $2-5$ & $6-10$ & $\begin{array}{l}11 \text { и } \\
\text { више }\end{array}$ & 0 & $\begin{array}{l}\text { до } \\
5 \%\end{array}$ & $5-10 \%$ & $\begin{array}{c}10- \\
20 \%\end{array}$ & $\begin{array}{l}\text { Преко } \\
20 \%\end{array}$ \\
\hline РЕПУБЛИКА СРБИЈЕ & 4709 & 1176 & 81 & 424 & 433 & 235 & 11 & 15 & 68 & 129 & 953 & 4 & 39 & 159 & 637 & 337 \\
\hline СРБИЈА- СЕВЕР & 624 & 53 & 0 & 5 & 17 & 27 & 2 & 0 & 4 & 1 & 46 & 0 & 0 & 0 & 36 & 17 \\
\hline Београдски регион & 157 & 6 & & & 2 & & & & & & 6 & & & & 2 & 4 \\
\hline Регион Војводина & 467 & 47 & & 5 & 15 & 27 & 2 & & 4 & 1 & 40 & & & & 34 & 13 \\
\hline СРБИЈА-ЈУГ & 4085 & 1123 & 81 & 419 & 416 & 208 & 9 & 15 & 64 & 128 & 907 & 4 & 39 & 159 & 599 & 322 \\
\hline $\begin{array}{l}\text { РегионШумадије и } \\
\text { Западне Србије }\end{array}$ & 2112 & 623 & 12 & 187 & 259 & 165 & 2 & 3 & 15 & 61 & 542 & 1 & 5 & 44 & 332 & 241 \\
\hline $\begin{array}{l}\text { РегионЈужне и Источне } \\
\text { Србије }\end{array}$ & 1973 & 500 & 69 & 232 & 157 & 43 & 7 & 12 & 49 & 67 & 365 & 3 & 34 & 115 & 267 & 81 \\
\hline
\end{tabular}

учешће појединих старосних група у градским/општинским центрима, слична је као просек у Републици и у осталим регионима, становништво приградских насеља је нешто старије у односу на остала подручја, али је становништво сеоских насеља овог региона најстарије у Србији. Нешто више од четвртине $(26,5 \%)$ становништва у селима има 65 и више година, а младо становништво до 19 година учествује са $17,5 \%$.

Посматрано по областима, најстарија села имају Пиротска и Зајечарска област. У Пиротским селима преко две петине $(42,5 \%)$ чини становништво са 65 и више година, а сваки десети становник (10,2\%) млађи је од 19 година, док у селима Зајечарске области 37,4\% становника има 65 и више година, а младо становништво до 19 година учествује са 12,3\%. Преко 30\% старог становништва имају и села у Топличкој и Борској области. Демографски потенцијали села у осталим областима, изузев Подунавске области, такође су прилично исцрпљени.

На основу података на нивоу области, може се претпоставити да је у Србији, првенствено на Југу, мали број села са повољном структуром становништва, као основом економског и социјалног развоја. Преглед стања у насељима до 100 становника и 100 до 300 становника (Табела 5 и 6) показује да она практично немају демографских потенцијала и да су у поодмаклој фази демографског „одумирања”, пре свега у Региону Јужне и Источне Србије.

У 519 (око 83\%) насеља до 100 становника у Региону Јужне и Источне Србије становништво са 65 и више година учествује са преко 30\%, у 17 села (до 20 становника) сви становници 
су у овој старосној групи, а само у малом броју насеља (31) учешће старог становништва је мање од 20\%. Такође, у 265 села нема деце предшколског и основношколског узраста, у 68 има само по једно дете, а у 175 између двоје и петоро деце. Без млађе женске фертилне популације (20-39 година) је 223 села (35\%), а 118 села има само по једну жену ове старосне групе. У свему преовлађују села Пиротске, затим Топличке и Зајечарске области.

Слична је ситуација и у селима од 100 до 300 становника, када је реч о региону Јужне и Источне Србије. Преко $30 \%$ становништва старијег од 65 година имало је 301 насеље (око 60\%), без деце млађе од 14 година било је 7 насеља, а четвртина (26\%) је имала мање од десеторо деце овог узраста, три села нису имала млађе женско становништво, а у $30 \%$ села ова старосна група жена је учествовала са мање од 10\%. Ситуација у селима Шумадије и Поморавља је нешто повољнија. Нешто мање од трећине насеља је имало преко $30 \%$ становништва старијег од 65 година, а у четвртини је ова старосна група била заступљена са мање од 20\%. Без деце предшколског и основношколског узраста била су два села, а 12\% (79 насеља) је имало до десеторо деце овог узраста. Без млађе женске фертилне популације било је једно село, мање од $10 \%$ учешћа ове старосне групе је имало 49 села (8\% од укупног броја), а преко 20\% учешћа је имало око две петине села (241), углавном у Рашкој, и знатно мање у Златиборској и Мачванској области.

\section{Учешће жена у укупном становништву и према типу насеља}

Процес интензивног мигрирања млађих жена из сеоских насеља почео је крајем 60-их година 20. века. Међутим, тема миграција жена из сеоских насеља није била предмет систематских истраживања, обрађивана је у оквиру анализа општих миграционих токова из сеоских ка градским насељима, или између република бивше Југославије и миграција ван земље.

Све је јасније да опстанак и оживљавање села и рурални развој у целини у великој мери зависе од жена и њиховог положаја.

На националном нивоу у укупном становништву удео жена нешто је већи у односу на мушкарце (51,3\% : 48,7\%), што је и очекивано и слично демографској дистрибуцији у другим државама. Посматрано на нивоу функционалних целина, жене су знатно бројније од мушкараца на подручју Србија-Север (52\% : 48\%), у односу на подручје Србија-Југ $(50,6 \%: 46,4 \%)$, што потврђује чињеницу да жене више мигрирају/емигрирају из економски неразвијених подручја. Разлике се јављају и у зависности од типа насеља, а највише по старосним групама (Табела 7).

На нивоу Републике скоро две трећине жена $(65,9 \%)$ старости 20-39 година живи у градским насељима, што је за 4,3\% више од просека за укупну женску популацију Републике Србије. У приградским насељима живи 16,7\%, што је слично републичком просеку (17,0\%). Највећа разлика је у сеоским

\begin{tabular}{|c|c|c|c|c|c|c|}
\hline Подручје & Тип насеља & Укупно & $0-19$ & $20-39$ & $40-64$ & преко 65 \\
\hline \multirow{3}{*}{ РЕПУБЛИКА СРБИЈА } & градски и општински центри & 61,4 & 61,0 & 65,7 & 62,4 & 54,6 \\
\hline & пригрска насеља & 17,0 & 18,1 & 16,5 & 17,1 & 16,7 \\
\hline & остала (сеоска) насеља & 21,5 & 21,0 & 17,8 & 20,6 & 28,6 \\
\hline \multirow{3}{*}{ СРБИЈА - СЕВЕР } & градски и општински центри & 70,7 & 68,6 & 73,4 & 70,6 & 69,3 \\
\hline & пригрска насеља & 18,6 & 20,2 & 17,4 & 18,7 & 18,5 \\
\hline & остала (сеоска) насеља & 10,7 & 11,2 & 9,1 & 10,7 & 12,3 \\
\hline \multirow{3}{*}{ Београдски регион } & градски и општински центри & 81,9 & 79,5 & 83,1 & 81,8 & 82,7 \\
\hline & пригрска насеља & 12,7 & 14,6 & 12,4 & 12,7 & 11,0 \\
\hline & остала (сеоска) насеља & 5,4 & 5,9 & 4,5 & 5,4 & 6,3 \\
\hline \multirow{3}{*}{ Регион Војводине } & градски и општински центри & 60,8 & 59,6 & 64,1 & 60,7 & 58,0 \\
\hline & пригрска насеља & 23,8 & 24,8 & 22,3 & 24,0 & 24,7 \\
\hline & остала (сеоска) насеља & 15,3 & 15,6 & 13,6 & 15,3 & 17,3 \\
\hline \multirow{3}{*}{ СРБИЈА - ЈУГ } & градски и општински центри & 51,9 & 53,5 & 57,0 & 53,9 & 41,0 \\
\hline & пригрска насеља & 15,4 & 16,0 & 15,4 & 15,3 & 15,1 \\
\hline & остала (сеоска) насеља & 32,6 & 30,5 & 27,6 & 30,8 & 43,8 \\
\hline \multirow{3}{*}{$\begin{array}{l}\text { Регион Шумадије и Западне } \\
\text { Србије }\end{array}$} & градски и општински центри & 50,2 & 51,0 & 54,6 & 51,9 & 40,5 \\
\hline & пригрска насеља & 15,0 & 15,7 & 15,2 & 14,9 & 14,0 \\
\hline & остала (сеоска) насеља & 34,9 & 33,3 & 30,1 & 33,1 & 45,6 \\
\hline \multirow{3}{*}{$\begin{array}{l}\text { Регион Јужне и Источне } \\
\text { Србије }\end{array}$} & градски и општински центри & 54,3 & 57,0 & 60,1 & 56,5 & 41,7 \\
\hline & пригрска насеља & 16,0 & 16,3 & 15,6 & 15,8 & 16,5 \\
\hline & остала (сеоска) насеља & 29,7 & 26,7 & 24,2 & 27,7 & 41,8 \\
\hline
\end{tabular}

Ta6.7.

Дистрибуција жена према типу насеља и старосној групи - Попис 2011.

Tab. 7.

The distribution of women by type of settlement and age groups - Census 2011.

насељима у којима је заступљеност овог контингента 17,4\%, односно за 4\% мање од просека за укупну женску популацију у селима у Републици. Разлике су посебно велике на Југу Србије - у градским и општинским центрима 5,1\% више од просека за укупну женску популацију на овом подручју, а у сеоским $5 \%$ испод просека, и са већом разликом у региону Јужне и Источне Србије - 5,8\% изнад просека у градовима, а у селима 5,5\% испод просека у региону. Такође, код две „најстарије” области у Србији - Пиротска и Зајечарска - највећи је дебаланс у просторном размештају жена старости 20-30 година. У Пиротској области у градским и општинским центрима живи 71,9\% жена ове старосне групе, односно 8,6\% изнад просека за област (63,3\%), а у селима 8,5\% испод просека, док је у зајечарској области разлика већа - у 
градовима и општинским центрима 11,5\% изнад просека $(57,8 \%)$, а у селима 10,4\% испод просека за укупно женску популацију (28,6\%).

Ове разлике илуструју и подаци о односу мушкараца и жена у овој старосној групи и према типу насеља (Табела 8). Жене су бројније од мушкараца у најстаријој старосној групи и то у свим типовима насеља, што је последица биолошке чињенице да жене дуже живе. Посебну пажњу завређује полна структура у сеоским насељима у старосном контингенту 20-39 година, где је удео жена 46,5\%, односно мушкараца 53,5\%, при том, идентичан је однос у сеоским насељима у свим посматраним целинама.

Последица појачане миграције жена из сеоских насеља је демографски дебаланс који се огледа у великом броју неожењених мушкараца без породице и наследника. Овакво стање угрожава репродукцију и опстанак пољопривредних и сеоских газдинстава уопште, а неминовно убрзава процес демографског нестајања/гашења насеља.

\begin{tabular}{|c|c|c|c|c|c|c|}
\hline Подручје & Тип насеља & Укупно & $0-19$ & $20-39$ & $40-64$ & $\begin{array}{l}\text { преко } 65 \\
\text { година }\end{array}$ \\
\hline \multirow{3}{*}{ РЕПУБЛИКА СРБИЈА } & градски и општински центри & 52,2 & 48,6 & 50,3 & 53,0 & 58,5 \\
\hline & пригрска насеља & 50,1 & 48,5 & 47,6 & 49,5 & 57,1 \\
\hline & остала (сеоска) насеља & 49,7 & 48,5 & 46,5 & 47,8 & 57,0 \\
\hline \multirow{3}{*}{ СРБИЈА - СЕВЕР } & градски и општински центри & 52,7 & 48,7 & 50,7 & 53,4 & 59,6 \\
\hline & пригрска насеља & 50,3 & 48,5 & 47,6 & 49,8 & 58,3 \\
\hline & остала (сеоска) насеља & 49,9 & 48,7 & 46,4 & 48,7 & 58,7 \\
\hline \multirow{3}{*}{ Београдски регион } & градски и општински центри & 53,2 & 48,7 & 51,5 & 54,3 & 59,2 \\
\hline & пригрска насеља & 50,2 & 48,4 & 48,6 & 50,7 & 54,8 \\
\hline & остала (сеоска) насеља & 50,0 & 48,8 & 47,3 & 49,3 & 56,1 \\
\hline \multirow{3}{*}{ Регион Војводине } & градски и општински центри & 52,1 & 48,6 & 49,7 & 52,5 & 60,1 \\
\hline & пригрска насеља & 50,4 & 48,6 & 47,1 & 49,4 & 59,7 \\
\hline & остала (сеоска) насеља & 49,9 & 48,7 & 46,1 & 48,4 & 59,6 \\
\hline \multirow{3}{*}{ СРБИЈА - ЈУГ } & градски и општински центри & 51,6 & 48,5 & 49,8 & 52,5 & 56,9 \\
\hline & пригрска насеља & 49,8 & 48,4 & 47,7 & 49,1 & 55,9 \\
\hline & остала (сеоска) насеља & 49,7 & 48,4 & 46,5 & 47,6 & 56,5 \\
\hline \multirow{3}{*}{$\begin{array}{l}\text { Регион Шумадије и } \\
\text { Западне Србије }\end{array}$} & градски и општински центри & 51,8 & 48,6 & 50,0 & 53,0 & 57,0 \\
\hline & пригрска насеља & 49,9 & 48,2 & 47,9 & 49,6 & 56,1 \\
\hline & остала (сеоска) насеља & 49,6 & 48,7 & 46,6 & 47,7 & 56,4 \\
\hline \multirow{3}{*}{$\begin{array}{l}\text { Регион Јужне и Источне } \\
\text { Србије }\end{array}$} & градски и општински центри & 51,3 & 48,4 & 49,6 & 52,0 & 56,9 \\
\hline & пригрска насеља & 49,7 & 48,6 & 47,4 & 48,4 & 55,8 \\
\hline & остала (сеоска) насеља & 49,8 & 48,0 & 46,5 & 47,4 & 56,7 \\
\hline
\end{tabular}

Ta6. 8.

Учешће жена у укупном становништву и по старосним групама - Попис 2011.

Tab. 8.

The share of women in the total population and by age group - Census 2011

\section{ЗАКЉУЧАК}

Вишедеценијско избегавање/занемаривање просторне димензије развоја има за последицу поларизацију у Србији у сваком погледу (економском, социјалном, демографском). у првој деценији 21. века вишеслојна регионална поларизованост простора Србије још је више продубљена. У погледу демографског развоја овај период су обележиле изразита депопулација, слабљење демографских потенцијала, старење становништва и повећање неравномерности у територијалном размештају становништва (драстично пражњење сеоских и неразвијених подручја).

Људски ресурси постају ограничавајући фактор развоја на све ширем простору, а старење становништва неминовно доводи до проблема недостатка радне снаге. Истовремено, Србија је у изештају Светског економског форума из 2011. године (World Economic Forum), рангирана међу првих десет земаља које су под утицајем „одлива мозгова”, што свакако има негативне последице на конкурентност, модернизацију и развој земље (Pejić-Sokić, Grečič 2012).
Са највећим проблемима суочавају се рурална подручја, деценијама маргинализована и ван сфере интересовања владајуће елите. Социјални и економски проблеми ових подручја идентификовани су у бројним националним стратегијама, а укључивање руралне популације у друштвене токове и процесе развоја од кључног је значаја с обзиром да у овим подручјима живи више од четвртине становника. Популациона политика у сеоским насељима морала би да се заснива и на одговарајућој, међусобно координисаној, економској, социјалној, руралној, регионално-развојној политици, битно различитој од досадашње која је младе људе, нарочито жене, просто истискивала из села. Међутим, како Тим за социјално укључивање и смањење сиромаштва наводи, реалне потребе руралног становништва и даље су углавном маргинализоване, а проблеми развоја руралних подручја у Србији још увек се не третирају као интегрални део укупног друштвено-економског развоја. Приступ решавању проблема руралних подручја још увек има секторски 
карактер, углавном кроз подршку пољопривреди (Budućnost sela Srbije, 2012: 64). Јачање капацитета ових локалних заједница је од суштинске важности и за њихов опоравак. У том смислу, потребно их је укључити у IPA програме ЕУ за регионални и рурални развој у области јачања људских капацитета.

С друге стране, сасвим је извесно да услед деловања дуготрајних негативних демографских трендова немају сва насеља реалне шансе за опстанак. У Програму имплементације Просторног плана PC 2010-2020 за период 2011-2015. међу стратешким приоритетима је и студија o зонама и подручјима реално могуће демографске ревитализације у склопу одрживог регионалног развоја. Ово захтева системско и мултисекторско истраживање.

у србији је у последњој деценији усвојен велики број стратегија и акционих планова усмерен према различитим групама и категоријама становништва (жене, деца, омладина, стари, сиромашни). Међу њима је и Стратегија за подстицање рађања (усвојена 2008. године) са практичним мерама како би се зауставила изразита демографска „ерозија". Усвајање Стратегије је тек први корак у одговору државе на изузетно низак фертилитет, а успех ће умногоме зависити од операционализације и спровођења предложених мера и активности. По први пут у Србији, Влада Републике Србије усвојила је 2009. године и Стратегију за управљање миграцијама (Sl. glasnik RS, br. 59/09). Како наводи Рашевић, највећи део овог документа се бави образлагањем контекста у коме се он доноси, а мањи део је посвећен циљевима државе везаним за миграторну политику и начин на који они могу да се остваре (Rašević, 2009: 61).

Такође, по први пут је сачињен и документ Миграциони профил Републике Србије (усвојен на седници Владе Републике (рбије фебруара 2012. године). Основна идеја Миграционог профила је да служи као инструмент који ће помоћи државним актерима у планирању адекватних миграционих политика, као и представницима цивилног друштва и академске заједнице у анализи актуелних миграционих токова. Према подацима у овом документу, у погледу унутрашњих миграција, у 2012. години настављен је тренд претежног досељавања у градска насеља (68\% миграната, око 83.000 лица), а према полној структури досељеног становништва, већину чине жене $(56,8 \%)$.

Какве ће резултате постићи примена усвојених докумената у подстицању природног раста становништва, задржавању становништва, пре свега млађе женске популације и привлачењу имигрантата, као и других развојних докумената, умногоме зависи од економске ситуације, али и од међусобне координације демографског и регионалног концепта развоја Србије. Очигледно да до сада није постојала међусобна координација, као ни ефикасни инструменти за њихову примену.

\section{Литература:}

Budućnost sela Srbije 2012, Tim za socijalno uključivanje i smanjenje siromaštva, kabinet potpredsednice Vlade za evropske integracije, Vlada Republike Srbije, Beograd, str. 1 156

Veselinov, V. (1987) Sumrak seljaštva, Beograd, Ekonomika

Izveštaj o razvoju Srbije 2012, Ministarstvo za regionalni razvoj i lokalnu samoupravu, sektor za strateške analize i istraživanja, Beograd 2013.

Jokić V., K. Petovar , M. Vujošević (1999) Demografski procesi u Srbiji devedesetih - sa osvrtom na Kolubarski lignitski Basen, u: Korišćenje resursa, održivi razvoj i uređenje prostora 4, Beograd, Institut za arhitekturu i urbanizam Srbije, str. 169-183.

Manić, S., D. Azdejković (2012) Potencijalni efekti demografske tranzicije na održivu konkurentnost, Ekonomski horizonti, maj-avgust 2012, godište XIV, sv. 2, Ekonomski fakultet Univerziteta u Kragujevcu, str.111-120. http://www.horizonti. ekfak.kg.ac.rs/sites/default/files/casopis/2012_2/SR/Manic Azdejkovic.pdf

Petovar, K., M. Vujošević (1996) Razmeštaj i kretanje stanovništva kao faktor održivog (regionalnog) razvoja Srbije, u: Korišćenje resursa, održivi razvoj i uređenje prostora, Posebna izdanja br. 30, Beograd, Institut za arhitekturu i urbanizam Srbije, str. 169-182.

Petovar, K., M. Vujošević, (1998) Uticaj nekih demografskih faktora na ostvarivanje koncepta održivog razvoja u seoskim područjima Kosova i Metohije, u: Korišćenje resursa, održivi razvoj i uređenje prostora, posebna izdanja, br. 35, Beograd, Institut za arhitekturu i urbanizam Srbije, str. 243-264.

Penev, G., R. Stevanović (2002) Smanjenje ili povećanje stanovništva? Prvi rezultati Popisa 2002. u Centralnoj Srbiji, Stanovništvo br. 1 - 4, Beograd

Pejić-Sokić, P., V. Grečić (2012) Socijalni uticaji emigarcija i migracija selo - grad u Centralnoji istočnoj Evropi, VT/2010/00, sažetak, Evropska Komisija GD za zapošljavanje, socijalne poslove i inkluziju ec.europa.eu/social/BlobServlet?docld=88 25\&langld =sr

Prirodno kretanje stanovništva u Republici Srbiji 1961-2010, podaci po opštinama (2012), Beograd, Rebulički zavod za statistiku Srbije

Program implementacije Prostornog plana RS 2010-2020 za period 2011-2015, Republička agencija za prostorno planiranje (2011)

Prostorni plan opštine Bor, Nacrt plana (2013), Beograd, Institut za arhitekturu i urbanizam Srbije

Prostorni plan područja posebne namene Borsko-majdanpečkog rudarskog basena - Koncept plana(2013), Beograd, Institut za arhitekturu i urbanizam Srbije

Popis stanovništva, domaćinstava i stanova u 2002. godini, Uporedni pregled broja stanovnika 1948, 1953, 1961, 1971, 1981, 1991. i 2002. godine po naseljima, knjiga 9, (2004), Beograd, RZS

Popis stanovništva, domaćinstava i stanova u 2011 godini, Starost i pol po naseljima, knjiga 2 (2012), Beograd, RZS

Radovanović, S. (1995) Stanovništvo gradova i sela u Srbiji posle Drugog svetskog rata, Glasnik Etnografskog instituta SANU, knj. XLIV, Beograd, str. 55-60.

Rašević, M. (2009): Populaciona politika u Srbiji: stanje i očekivanja, Stanovništvo br. 2, Beograd, str. 53-65.

Strategiju za upravljanje migracijama, Službeni glasnik RS, br. $59 / 09$

Strategija za podsticanje rađanja, http://www.srbija.gov.rs/vesti/ dokumenti_sekcija.php?id=45678 